\title{
Joshua's Celestial Miracle was not an Eclipse: the Long and the Short
}

\section{Marinus Anthony van der Sluijs}

\begin{abstract}
Humphreys \& Waddington have recently suggested that the Biblical account involving Joshua's control of the sun and moon (Joshua 10. 1-15) was inspired by an annular eclipse. Going by the text as given, it is shown that the explanation as an eclipse, whether annular or total, is unacceptable on calendrical, philological and physical grounds alike. The story's possible historicity cannot be properly evaluated until it is placed in two cross-cultural and sometimes overlapping contexts: ritual utterances before battle designed to divine the outcome or provoke divine intervention in it and the mythology of solar arrests, reversals and radical alterations of the length of day. 'Solar magic' emerges as a common archaic practice in real life as well as legend. Some literary parallels are cited which have never before been linked with Joshua. All things considered, the tale may have originated as an embellished memory of some extraordinary natural event other than an eclipse, coinciding with a historical battle. A tempting possibility is the aerial passage of a fragmenting bolide, producing a meteorite shower and nocturnal illumination.
\end{abstract}

\section{Introduction}

Despite centuries of speculation by scholars and scientists alike, the famous Biblical miracle involving Joshua's control of the sun and moon has resisted a satisfactory explanation in secular terms. The incident is set in the early stages of the Israelite conquest of Canaan, just after the invaders have destroyed the cities of Jericho and $\mathrm{Ai}$ and acquired Gibeon. When five Amorite kings conspire against them, Joshua and his army march towards them throughout the night from their base at Gilgal, defeat them at Gibeon and pursue the survivors in the direction of Beth Horon. At that point, a sudden bombardment by hailstones claims the lives of many more of the locals and - either simultaneously or directly afterwards - something most peculiar befalls the appearance of the sun and moon:

Marinus Anthony van der Sluijs, 'Joshua's Celestial Miracle was not an Eclipse: the Long and the Short', Culture and Cosmos, Vol. 23 no 1, Spring/Summer 2019, pp. 21-69.

www.CultureAndCosmos.org 
22 Joshua's Celestial Miracle was not an Eclipse: the Long and the Short

12a 'āz yadabbēr yəhōšua' layhwē bəyōm tēt yahwē 'ęt-hā'ěmorì lipnē banè yiśrā'ēl wayyōmęr la 'ènēe yiśrā'ēl

${ }^{12 b}$ šęmęš bagib ‘ōn dōm wayārēah ba 'ēmęq 'ayyālōn

13a wayyiddom haššęmęš wayārēah 'āmād 'ad-yiqqom gōy 'oyəbāyw

${ }^{13 \mathrm{~b}}$ hălō-hī katūbā 'al-sēpęr hayyāšār wayya ‘ămod haššemęš

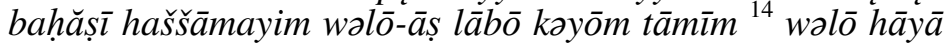
kayyōm hahü lapānāyw wo'ahăăāyw lišmoa' yahwę baqōl 'ǐs ...

12a Then Joshua spoke to Yahweh on the day when Yahweh delivered up the Amorite before the children of Israel and said before the eyes of Israel:

${ }^{12 \mathrm{~b}}$ Sun, stop at Gibeon, and Moon, at the Valley of Ayyalon!

${ }^{13 a}$ And the sun stopped and the moon halted until the nation avenged itself upon its enemy.

${ }^{13 b}$ Is this not written in the Book of the Just? And the sun halted in the middle of the sky and did not hasten to go like an entire day. ${ }^{14}$ And there has been no day like that before it or after it, that Yahweh listened to the voice of a man ...

That the author of the chapter was citing from an earlier source entitled Sépar hayyāšăr (Book of Jasher or Book of the Just) implies the possibility, though by no means the certainty, that he had a different understanding of the event than his source. The comment directly following the reference could have been either a paraphrase or popular memory in agreement with the Book of the Just or the author's subjective and imaginative take. ${ }^{2}$

${ }^{1}$ Joshua, 10. 12-14, eds. Karl Elliger, Wilhelm Rudolph \& Adrian Schenker, Biblia Hebraica Stuttgartensia (Stuttgart: Deutsche Bibelgesellschaft, $1997^{5}$ ), p. 371, author's translation.

${ }^{2}$ Thomas B. Dozeman, Joshua 1-12; A New Translation with Introduction and Commentary ('The Anchor Yale Bible', 6B; New Haven: Yale University Press, 2015), pp. 439, 441-445, 450; Koert van Bekkum, From Conquest to Coexistence; Ideology and Antiquarian Intent in the Historiography of Israel's Settlement in Canaan ('Culture \& History of the Ancient Near East', 45; Leiden: Brill, 2011), pp. 282-284; Heinrich Holzinger, Das Buch Josua Erklärt ('Kurzer

Culture and Cosmos 
Two British scientists - physicist Colin John Humphreys and astrophysicist W. Graeme Waddington - have recently suggested that the episode was inspired by an annular eclipse, specifically the one of 30 October 1207 BCE. $^{3}$ Occurring in the late afternoon, the eclipse would have created the illusion of a 'double dusk', with only a short interval of about 28 minutes of normal daylight in-between. This effectively turns the miracle's traditional interpretation as a 'long day ${ }^{4}$ on its head. Supposing that the Israelites experienced the dim atmosphere during the eclipse as an early onset of dusk, it would have been natural for them to wonder why the sun - at least partly - remained visible in a dusky sky for so long, while it normally sets below the horizon before the dusk even commences. For the crux posed by the words kayōm tämim ('like an entire day'), the authors adapted an ingenious solution: instead of approximating the event's duration ('for like an entire day'), the expression could be contrasting the special day with a day of normal length, on which the sun suffers no delay in disappearing from view. ${ }^{5}$

Hand-Commentar zum Alten Testament', 6; Tübingen: J. C. B. Mohr [Paul Siebeck], 1901), pp. 37, 40.

${ }^{3}$ Colin John Humphreys \& W. Graeme Waddington, 'Solar Eclipse of 1207 BC Helps to Date Pharaohs', Astronomy \& Geophysics, 58. 5 (1 October 2017), 3942.

${ }^{4}$ e.g., van Bekkum, From Conquest to Coexistence, pp. 291-295; Moshe Weinfeld, 'Divine Intervention in War in Ancient Israel and in the Ancient Near East', in Hayim Tadmor \& Moshe Weinfeld (eds.), History, Historiography and Interpretation; Studies in Biblical and Cuneiform Literatures (Jerusalem: The Magnes Press, 1983), pp. 146-147. Several commentators pointed out the logical flaw that pausing the moon would not affect the length of day, e.g., Abram Smythe Palmer, A Misunderstood Miracle: An Essay in Favour of a New Interpretation of 'The Sun Standing Still' in Joshua X. 12-14 (London: Swan Sonnenschein, Lowrey \& Co., 1887), pp. 52-53; Robert Eisler, 'Joshua and the Sun', The American Journal of Semitic Languages and Literatures, 42.2 (1926): p. 84; Jan Alberto Soggin, Joshua; A Commentary (tr. R. A. Wilson; 'The Old Testament Library'; Philadelphia, Pennsylvania: The Westminster Press, 1972), p. 122; Kang Sa-Moon, Divine War in the Old Testament and in the Ancient Near East ('Beiheft zur Zeitschrift für die alttestamentliche Wissenschaft', 177; Berlin: Walter de Gruyter, 1989), p. 157.

5 The reading of the words as a reference to a normal day had been aired long before: Giuseppe Barzilai, Un Errore di trenta secoli; Discorso accademico (Trieste: Lloyd Austriaco, 1868), pp. 9-10; [Alfred] Edersheim, Israel in Canaan under Joshua and the Judges (London: The Religious Tract Society, 1877), p. 82; some authorities cited with disapproval in Smythe Palmer, Misunderstood Miracle, pp. 35 note 2, 92; Robert Dick Wilson, 'What Does "The Sun Stood 
Hence, the second part of verse $13 \mathrm{~b}$ could be freely rendered as follows: 'And the sun stopped (shining) in the middle of the sky and did not hasten to set like (it does on) an entire day (this day not being entire, but unusually short). ${ }^{6}$ Presumably, Humphreys \& Waddington reckoned that this unexpected abbreviation of the period of daylight assisted the Israelites by providing a further cover of darkness in addition to their surprise night-time attack on the same morning. Impressive on the surface, their proposition is of some importance, for if it be correct it would concern 'the oldest solar eclipse recorded'. ${ }^{7}$ Does it stand up to scrutiny?

\section{Not an Eclipse Record}

Attempts to explain the legendary event as a solar eclipse have a long history, going back even further than Humphreys \& Waddington indicate.

Still” Mean?', The Princeton Theological Review, 16. 1 (1918): pp. 47, 50. Van Bekkum (From Conquest to Coexistence, p. 282 note 152) objected to this interpretation that it 'would most likely require the reading ביום instead of However, it would be entirely grammatical - though not mandatory - for the construction kibyom ('like on a day'), with double preposition, to lose its second preposition, $c f$. Paul Joüon \& Takamitsu Muraoka (eds.), A Grammar of Biblical Hebrew ('Subsidia Biblica', 14/I; Rome: Editrice Pontificio Istituto Biblico, 1993), p. 491.

${ }^{6}$ As a second interpretation of this difficult phrase, Humphreys \& Waddington ('Solar Eclipse': p. 41) reasoned that the eclipse was so Mesmerising that it distorted the Israelites' impression of time, making it seem 'long and drawn-out'. In support, they cited Sudanese witnesses perceiving the two minutes of totality of the eclipse of 18 July 1860 as two hours (Mahmoud-Bey [Maḥmūd Aḥmad Hamdī al-Falakī], 'Rapport à son Altesse le vice-roi d'Egypte sur l'éclipse totale du 18 Juillet, observée à Dongolah', ..., Extrait', Comptes rendus hebdomadaires des séances de l'Académie des sciences, 51. 19 (5 November 1860): p. 684 = Rapport a Son Altesse Mohammed Saïd, Vice-Roi d'Égypte, sur l'éclipse totale de soleil observée a Dongolah (Nubie), le 18 Juillet 1860 (Paris: Mallet-Bachelier, 1861): p. 14). However, these were obviously exaggerating, employing a colloquial style discordant with the spirit of the book Joshua. Also, it would still be a long stretch to refer even to the subjective duration of the whole eclipse - from first contact to last - as 'an entire day'. And besides, the authors cannot have their cake and eat it, too: was the 'entire day' an altered perception of the eclipse itself, the normal day as compared to this 'mini-day' between the eclipse and true dusk, or perhaps the short period of ordinary daylight between the 'two dusks' itself?

${ }^{7}$ Humphreys \& Waddington, 'Solar Eclipse': pp. 39, 42, citing R. Wilson, 'What Does “The Sun Stood Still” Mean?'. 
Robert Wilson was not 'The first person to suggest that Joshua 10: 12-13 was referring to a solar eclipse, ${ }^{8}$ but had at least two precursors. ${ }^{9}$ Nevertheless, such attempts have never received widespread acceptance and with good reason. An eclipse interpretation is inadmissible, on the following eight grounds.

First, on the Hebrew ecclesiastical calendar the year begins around the spring equinox. The Israelites crossed the Jordan into Canaan on the 10th day of the 1 st month. ${ }^{10}$ Some seven months would then have had to pass between this event and the specific eclipse proposed by Humphreys \& Waddington, but 'in view of the promptitude with which all the contending parties acted, and were bound to act', according to Joshua, it is doubtful that more than four months could have elapsed until Joshua's victory over the Amorites. ${ }^{11}$ Another calendrical clue might be contained in Joshua 8. 30-35: if the reading of the law occurred on an anniversary of Moses' receipt of the law, it would have happened on the third day of the third month, ${ }^{12}$ furnishing another terminus post quem for the solar event.

Second, the Hebrew passage expresses the prodigy through two verbs: dāmam and 'àmad. Dictionaries give 'be or grow dumb, silent, still; cease' for dämam and 'take one's stand, stand' for 'amad. ${ }^{13}$ Whilst the authors, like earlier commentators, ${ }^{14}$ correctly point out that

\footnotetext{
${ }^{8}$ Humphreys \& Waddington, 'Solar Eclipse': p. 40.

9 Barzilai, Errore, pp. 8-16 ( $c f$. Edersheim, Israel, p. 82 note 1); [Claude Reignier] Conder, 'Notes on the Antiquities of the Book of Joshua', Palestine Exploration Quarterly, 31.2 (1899), 161-162.

${ }^{10}$ Joshua, 4. 19; cf. 5. 10.

${ }^{11}$ Edward Walter Maunder, The Astronomy of the Bible; An Elementary Commentary on the Astronomical References of Holy Scripture (London: T. Sealey Clark \& Co., 1908), pp. 360, 364.

${ }^{12}$ Maunder, Astronomy of the Bible, pp. 356, 364; 'A Misinterpreted Miracle', The Expositor, 10. 4 (October 1910): p. 363.

${ }^{13}$ Francis Brown, Samuel Rolles Driver \& Charles Augustus Briggs (eds.), A Hebrew and English Lexicon of the Old Testament with an Appendix Containing the Biblical Aramaic Based on the Lexicon of William Gesenius as Translated by Edward Robinson Late Professor in the Union Theological Seminary, New York

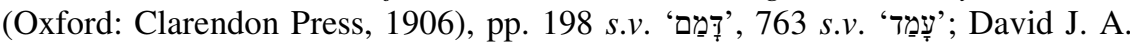
Clines (ed.), The Dictionary of Classical Hebrew, vol. 2: ו-ב (Sheffield: Sheffield

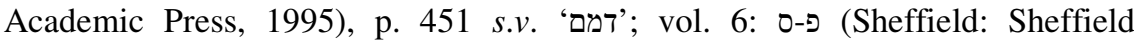
Phoenix Press, 2011), p. 463 s.v. 'עמד'.

${ }^{14}$ Mirroring their interpretation of 'to stop' as 'to cease shining', Barzilai (Errore, p. 10) and Smythe Palmer (Misunderstood Miracle, pp. 37, 56, 94 note
} 
motionlessness is not necessarily implied by damam, it is by 'amad - and the text uses the latter for the moon as well as the sun. ${ }^{15}$ Most likely, both verbs are here used in the sense of a cessation of motion, as they indisputably are - again juxtaposed - in 1 Samuel 14. 9. ${ }^{16}$ During an eclipse, of course, the sun and moon do not experience any change in their apparent movement.

Third, consultation of early translations and paraphrases of the Hebrew Bible is germane because a continuous educational tradition could have joined their composers to the texts' earliest authors; distortion of the original intention has undoubtedly occurred at times, but will need to be demonstrated on a case-by-case basis. It is, accordingly, not without significance that all versiones antiquae support the understanding that Joshua caused the sun and moon to halt, thereby lengthening the day. For the two Hebrew verbs in question, the Septuagint (between 285 and 132 BCE) employs only forms of the verb histēmi ('to stand') and the cognate

$\mathrm{X}$ ) contended that the sun's reluctance 'to go' (verse 13b) referred to the length of time it took for the restoration of its light after the darkness of an eclipse and a thunderstorm respectively, but this contravenes the recognised range of meanings of the verb $b \bar{a}$ ('to go' or 'to go in', as in 'to move' or 'to set').

${ }^{15}$ Cf. van Bekkum, From Conquest to Coexistence, pp. 115, 281-282, though others argued unconvincingly that even 'amad in this context signifies a blotting out of the light: Smythe Palmer, Misunderstood Miracle, pp. 35-36; John Day, Yahweh and the Gods and Goddesses of Canaan ('Journal for the Study of the Old Testament Supplement Series', 265; Sheffield: Sheffield Academic Press, 2000), p. 155 note 16. John Gray (Joshua, Judges and Ruth ['The Century Bible'; London: Thomas Nelson and Sons, 1967], p. 110) dispensed with both instances of 'amad, suggesting that the first one (verse 13a) does not fit the metre and the second one (verse 13b) was the clueless comment of a later scribe. This is wishful thinking, not judicious exegesis. Wilson ('What Does "The Sun Stood Still” Mean?': pp. 46-47, 49-50, 52; cf. Eisler, 'Joshua and the Sun': pp. 81-82) compared the use of 'amad here to Babylonian astrological terminology in which the equivalent word denotes 'the point, or place, in the heavens at which a star ceases to go in one direction and begins its return journey to its starting-point'. He did not confront the obvious implication that the Joshua passage would then be communicating a reversal in the direction of the course of the sun and moon, which has nothing to do with eclipses and would - unlike for planets - be no less anomalous than a pausing of these bodies. See below, however, for more on irregular reversals of direction.

16 Dozeman, Joshua, pp. 432-433, 442; van Bekkum, From Conquest to Coexistence, pp. 115, 289 note 170; Smythe Palmer, Misunderstood Miracle, p. 35 note 3 .

Culture and Cosmos 
noun stásis ('position, standing'): Stêttō ho hếlios ... kaì hē selếnē ... kaì éstē ho hếlios kaì hē selénēe en stásei ... kaì éstē ho hếlios ... ${ }^{17} \mathrm{~A}$ literal translation of the entire passage is:

'Let the sun stand at Gabaon, and the moon at the ravine of Ailon.'

And the sun stood still, and the moon was in position until God avenged himself on their enemies, and the sun stood in midheaven; it did not go forward to set until the end of one day. ${ }^{18}$

In the Vetus Latina (2nd century CE), the pertinent constructions are forms of sto ('to stand'): Stet sol in Gabaon, \& luna contra vallem Ajalon. / Stetit sol \& luna in statione, donec ultus est populus de inimicis suis. Et stetit sol in medio calo, \& non accedebat in occasum, \& in finem

${ }^{17}$ Joshua, 10. 12-13 (Septuagint), ed. Alfred Rahlfs, Septuaginta id est Vetus Testamentum Graece iuxta LXX Interpretes, vol. 1: Leges et Historiae (Stuttgart: Privilegierte Württembergische Bibelanstalt, 19504), pp. 370-371.

18 as above, tr. Leonard J. Greenspoon, in Albert Pietersma \& Benjamin G. Wright, A New English Translation of the Septuagint and the Other Greek Translations Traditionally Included under that Title (New York: Oxford University Press, 2007), p. 183. A. Graeme Auld (Joshua; Jesus Son of Naue in Codex Vaticanus ['Septuagint Commentary Series'; Leiden: Brill, 2005], pp. 3233) translated katà Gabaōn, katà pháragga Ailōn and katà méson tou ouranou as 'over Gabaōn', 'over the ravine Ailōn' and 'over the middle of the sky' respectively. For 'in position', he offered 'in stationariness'. Dozeman (Joshua, p. 527, cf. 433) translated èmýnato ... toùs echthroùs autōn as 'defended against their enemy' instead of 'avenged himself on their enemies'. Differences between the Masoretic text and the Septuagint were carefully noted in Dozeman, Joshua, pp. 427-452; van Bekkum, From Conquest to Coexistence, pp. 106-117; Holzinger, Das Buch Josua, pp. 34-37. Relevant here are that the Septuagint identifies the antagonists as Jebusites in verse 5, but Amorites in verses 6 and 12 (cf. Dozeman, Joshua, pp. 430, 526), and that it supports an alternative translation of the Hebrew for 'the nation avenged itself upon its enemy' as 'he avenged himself upon the nation of his enemy', inserting the word for God (theòs) as the subject (cf. pp. 425, 433, 527); Holzinger (Das Buch Josua, p. 35) opined that this was a typographical error for éthnos ('nation'). Despite its omission of verse 15, it is not at all clear that the Septuagint counts the execution of the kings (Joshua 10.16-27) among the events of the extended day, contra Dozeman, Joshua, pp. 433, 439, 441, 451; Maunder, Astronomy of the Bible, p. 376; see van Bekkum, From Conquest to Coexistence, pp. 116-117.

Culture and Cosmos 
28 Joshua's Celestial Miracle was not an Eclipse: the Long and the Short

diei unius. ${ }^{19}$ That is to say: 'Let the sun stand still in Gabaon, \& the moon over against the valley Ajalon. / The sun stood still \& the moon at its station, until the people had avenged itself on its enemies. And the sun stood still in mid-heaven, \& did not move towards the west, \& in the limit of one day.' Jerome's Vulgate (4th century CE) uses the same verb and a negated form of moveo ('to move'): Sol, ... ne movearis, et luna ... Steteruntque sol et luna ... Stetit itaque sol ... ${ }^{20}$ The full passage translates as:

'Move not, $\mathrm{O}$ sun, over against Gibeon, nor thou, $\mathrm{O}$ moon, over against the valley of Aijalon.' And the sun and the moon stood still till the people revenged themselves of their enemies. Is not this written in the Book of the Just? So the sun stood still in the midst of heaven and hasted not to go down the space of one day. There was not before nor after so long a day, the Lord obeying the voice of a man and fighting for Israel.

As if to remove any lingering doubt, the passage concludes with the explicit characterisation of the event as 'so long a day' (tam longa dies), a nuance which is absent from the Hebrew original, the Septuagint and the Vetus Latina. In sum, although the ancient text witnesses exhibit subtle variations between them, they are unanimous regarding the stasis of the sun and moon.

The Babylonian Talmūd reveals that the rabbinical sages all understood the behaviour of sun and moon in Joshua 10 as a momentary suspension of their movements, but variously calculated the duration of

19 Joshua, 10. 12-13 (Vetus Latina), ed. Pierre Sabatier, Bibliorum Sacrorum Latince Versiones Antiqua, seu Vetus Italica, et Catera quacunque in Codicibus Mss. \& Antiquorum Libris Reperiri Potuerunt: Qua cum Vulgata Latina, \& cum Textu Graco Comparantur. Accedunt Prafationes, Observationes, ac Nota, Indexque Novus ad VULGATAM è Regione Editam, idemque Locupletissimus, vol. 1 (Reims: Reginaldus Florentain, 1743), p. 413.

${ }^{20}$ Joshua, 10. 12-13 (tr. Jerome, Vulgate), ed. Michaele Tvveedale, Biblia Sacra juxta Vulgatam Clementinam; Editio Electronica (London: Council of Bishop's Conference of England and Wales, 2005), p. 125.

${ }^{21}$ as above, tr. Swift Edgar, The Vulgate Bible; Douay-Rheims Translation, vol. 2: The Historical Books, vol. 2A ('Dumbarton Oaks Medieval Library', 4; Cambridge, Massachusetts: Harvard University Press, 2011), pp. 52-53, but with contra translated as 'over against' instead of 'toward' - according to the Hebrew bə-.

Culture and Cosmos 
the long day as lasting 24, 36 or 48 hours; they interpreted the words 'and did not hasten to go' as a second episode of stasis close to sunset which followed the first one 'in the middle of the sky' (verse 13b) and differed as to whether the 'whole day' referred only to these two periods of motionlessness or also included the intermittent period of movement or the normal daylight hours preceding the first intervention. ${ }^{22}$

Two early paraphrases, too, support the traditional reading. Habakkuk (late 7th century BCE) thus alludes to the event:

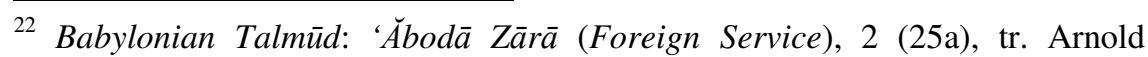
Mishcon, in Arnold Mishcon \& Abraham Cohen, 'Abodah Zarah; Translated into English with Notes, Glossary and Indices ('The Babylonian Talmud'; 'Seder Nezikin'; London: The Soncino Press, 1935), pp. 124-125 with 124 note 10. Rabbi Abraham Šālōm (1430-c1492) explained the second stage as dilatory rather than stagnating: 'the stoppage and the slow movement both took place: ... God, knowing that for the object of taking vengeance on the enemy, it would not be suitable to stay the sun in its course, and making it revolve slowly would not afford sufficient time, he did both: namely, he stayed the sun's motion at its meridian, that it might be perceptibly seen, and then regulating the miracle in conformity to the order of nature, he caused it to decline slowly until vengeance was effected; so that between the time of its motion being stopped, and its continuing its course, he says six hours passed, and therefore explains the text, "the sun stood still in the midst of heaven": that is, when its course was staid at noon, "and did not hasten to go down", means it afterwards declined at a slow rate, and "like a complete day" implying that between midday and night, there intervened twelve hours, or a duration of time equal to entire daylight of twelve hours. Consequently, that artificial day was eighteen hours' length' - Abraham Šālōm, Navē Šălōm (Dwelling of Peace), paraphrased in Mənaššę bęn Yiśrā'èl, El Conciliador, on Joshua 10. 12, tr. Elias Hiam Lindo, The Conciliator of R. Manasseh ben Israel; A Reconcilement of the Apparent Contradictions in Holy Scripture, to which Are Added Explanatory Notes, and Biographical Notices of the Quoted Authorities, vol. 2: The Prophets and Hagiography (London: Duncan and Malcolm, 1842), p. 17; not yet identified in Abraham Šālōm (אפר נוה (א. שלם), שלום (modern reprint; Jerusalem: publisher not stated, 1966-1967). The entire period of daylight would thus have amounted to 24 hours as opposed to the normal 12. The problem with expecting too much precision from the words 'like an entire day' is that Bronze Age people would have lacked the means to measure the passage of time if the celestial 'timepieces' were not moving (compare Genesis 1. 14-18). 
30 Joshua's Celestial Miracle was not an Eclipse: the Long and the Short

The sun and moon stood still in their habitation;

At the light of Your arrows they went,

At the shining of Your glittering spear. ${ }^{23}$

And an apocryphal work dated to $c 200-175$ BCE praises Joshua as follows: 'Was it not by his hand that the sun was shackled, / and one day became as two? ${ }^{24}$ A special case is Josephus' rendition (c94 CE). Omitting any explicit mention of the luminaries, it is nonetheless adamant about the altered length of day:

... Iesous ... learned as well the cooperation of God, signified to him by thunder, the discharge of lightning bolts and a greater than usual torrent of hail. In [sic] also happened that the day was increased further so that nightfall would not check the Hebrews' eagerness. The result was that Iesous took the kings hidden in a certain cave at Makchida and punished them all. That the duration of the day was prolonged and exceeded the usual on that occasion is disclosed in the writings present in the temple. ${ }^{25}$

Josephus apparently relied on the text in the Septuagint, taking it to mean that the kings were disposed of during the long day. The reference to temple scrolls deserves the benefit of the doubt.

Fourth, an annular eclipse is defined by the continued visibility of a thin bright ring of photospheric light even when the entire moon covers the sun. For the present occasion, Humphreys \& Waddington estimate

${ }^{23}$ Habakkuk, 3. 11, tr. Arthur Leonard Farstad, The Holy Bible Containing the Old and New Testaments; NKJV; New King James Version; Reference Edition (Nashville, Tennessee: Thomas Nelson, 1982), p. 825. The first line translates šęmęš yārēah 'āmad zabulā, eds. Elliger et al., Biblia Hebraica, p. 1053.

${ }^{24}$ Ecclesiasticus $=$ Wisdom of Ben Sirach, 46. 4, ed. Rahlfs, Septuaginta, p. 459, tr. Wright, in Pietersma \& Wright, New English Translation, p. 757. Enepodísthe is here derived from the verb pedáo ('to shackle'). A form of the verb 'āmad is again employed in the Hebrew original: MS. B, fol. 15 verso, ed. Pancratius Cornelis Beentjes, The Book of Ben Sira in Hebrew; A Text Edition of All Extant Hebrew Manuscripts and a Synopsis of All Parallel Hebrew Ben Sira Texts ('Supplements to Vetus Testamentum', 68; Leiden: E. J. Brill, 1997), p. 82.

25 Josephus, Antiquitates Judaicae (Jewish Antiquities), 5. 1.17 (60-61), tr. Christopher Begg, Judean Antiquities Books 5-7; Translation and Commentary ('Flavius Josephus; Translation and Commentary', 4; Leiden: Brill, 2005), p. 16. 'Iēsous' is the normal Greek form for 'Joshua'. 
that the maximum loss of solar output was $90 \%{ }^{26}$ As this is not $100 \%$ and even during total solar eclipses the sky remains five times brighter than with a full moon, ${ }^{27}$ one may legitimately enquire whether the sun could have been justifiably believed to have 'stopped shining'. Indeed, astronomers warned: 'The darkening of the sky is evident enough, and so is the drop in temperature, but neither effect is as marked as might be expected. In 1976 there was an annular eclipse visible from the Mediterranean, and both authors observed it from the island of Santorini ... Even in mid-eclipse, many of the local population took no notice, because they had not realised that anything unusual was happening. ${ }^{28} \mathrm{At}$ best, therefore, the sun would have imperfectly heeded Joshua's order to darken - a half-baked miracle.

Fifth, solar eclipses by their nature coincide with new moon, when the night is at its darkest in the lunar cycle. Humphreys \& Waddington felt that the Israelites were so 'well aware of this monthly period of lunar invisibility' that they consciously 'timed their surprise night-time attack at Gibeon to take advantage of the lack of natural night-time illumination at this time. ${ }^{29}$ To the contrary, in an age when man-made light pollution was practically non-existent it would have been all but impossible for a military unit on unfamiliar terrain to have 'marched all night from Gilgal' (kól-hallailā 'ālà min-haggilgāl) to Gibeon (verse 9) on a moonless night. ${ }^{30}$

Sixth, the moon's purported invisibility is hard to reconcile with Joshua addressing the moon. If the Hebrews were so 'well aware' of this phase that they capitalised on the darkness in their surprise offensive, there would have been no reason for Joshua to request that the moon withdraw from view. In addition, if the moon's performance entailed being invisible it would be meaningless to demand that the moon do so at

\footnotetext{
${ }^{26}$ Humphreys \& Waddington, 'Solar Eclipse': p. 41.

27 Alfred P. Smyth, 'The Solar Eclipse of Wednesday 29 October AD 878: Ninth-Century Historical Records and the Findings of Modern Astronomy', in Jane Roberts, Janet Laughland Nelson \& Malcolm Godden (eds.), Alfred the Wise; Studies in Honour of Janet Bately on the Occasion of her Sixty-Fifth Birthday (Cambridge: D. S. Brewer, 1997), p. 188.

28 Michael Maunder \& Patrick Moore, The Sun in Eclipse ('Practical Astronomy'; Berlin: Springer-Verlag, 1998), pp. 93-94.

${ }^{29}$ Humphreys \& Waddington, 'Solar Eclipse': p. 41.

${ }^{30}$ Edward Greswell, The Three Witnesses, and the Threefold Cord; Being the Testimony of the Natural Measures of Time, of the Primitive Civil Calendar, and of Antediluvian and Postdiluvian Tradition, on the Principal Questions of Fact in Sacred or Profane Antiquity (London: Rivingtons, 1862), p. 102.
}

Culture and Cosmos 
a specific location - the Valley of Ayyalon. Evidently, the story was premised on the moon's visible presence in the sky, which alone disqualifies a solar eclipse.

An advocatus diaboli might try and overcome these objections by positing that the Israelites or at least the author of Joshua understood that the darkening of the sun during a solar eclipse is due to the moon. Yet although it may not be all that difficult for a prescientific society to work this out, comparative ethnology shows that such a degree of astronomical insight was fairly uncommon around the world. ${ }^{31}$ In folklore, solar

${ }^{31}$ Some groups apparently understood the moon's involvement in solar eclipses: the Greek populace of the 5th century BCE (Plutarch, Life of Nicias, 23. 1-2 [538]), the Pipil in western El Salvador (Leonhard Schultze Jena, Indiana, vol. 2: Mythen in der Muttersprache der Pipil von Izalco in El Salvador [Jena: Gustav Fischer, 1935], pp. 98-99), the Nivaclé in Paraguay and northwest Argentina (Johannes Wilbert \& Karen Simoneau (eds.), Folk Literature of the Nivaklé Indians ['Folk Literature of South American Indians'; 'UCLA Latin American Studies', 66; Los Angeles: UCLA Latin American Center Publications, 1987], pp. 26-30) and the Yolngu in eastern Arnhem Land (William Lloyd Warner, $A$ Black Civilization; A Social Study of an Australian Tribe [New York: Harper \& Brothers Publishers, 1937], p. 538). Yet such beliefs must be treated with caution. Certainly, Plutarch astutely acknowledged that the Greeks of the stated period did not, conversely, appreciate the sun's part in lunar eclipses. There are cultures which seem to have had a hunch of the latter, e.g., the Nivaclé and in northern Guyana the Lokono (Claudius Henricus de Goeje, Philosophy, Initiation and Myths of the Indians of Guiana and Adjacent Countries ['Archives internationales d'ethnographie', 44; Leiden: E. J. Brill, 1943], pp. 39-40). However, at least one nation erroneously interpreted lunar eclipses as the sun under the guise of a dragon - swallowing the moon: the Kintaq group of Semang on the northwestern Malaysian peninsula (Paul Schebesta, Bei den Urwaldzwergen von Malaya; Mit 150 Abbildungen nach Originalaufnahmen und Skizzen des Forschers und einer Karte [Leipzig: F. A. Brockhaus, 1927], p. 229 = Among the Forest Dwarfs of Malaya [tr. A. Chambers; London: Hutchinson \& Co., c1928], p. 237). The Mantra group of Temuan on the southwestern Malaysian peninsula explained eclipses in the same way, but the reports do not make it clear whether these were lunar or solar - James Richardson Logan, 'The Orang Binua of Johore', The Journal of the Indian Archipelago and Eastern Asia, 1 (1847): p. 285; D. F. A. Hervey, 'The Měntra Traditions', Journal of the Straits Branch of the Royal Asiatic Society, 10 (December 1882): p. 190. Likewise, two Algerian Berber groups viewed eclipses as fights between the sun and moon, but the sources do not specify which type of eclipses; these groups are the Tidikelt (Louis Voinot, 'Le Tidikelt; Etude sur la géographie, l'histoire et les mœurs du pays', Bulletin de la Société de Géographie et d'Archéologie de la 
eclipses are overwhelmingly associated with a devouring monster, not the moon. Nor would it help to argue - as Humphreys \& Waddington did that belief in the moon's participation was inspired by the observation that the sun sports gibbous and crescentic forms before and after annularity, 'mimicking the form of the Moon' in a compressed lunar cycle $^{32}$ for in that case the resulting tradition would more likely have been that the sun 'became the moon' than that it and the moon stopped shining or moving. A universal mythological motif is, in fact, that the sun and moon once swapped functions, the moon formerly having outshone the sun. ${ }^{33}$ However, phases are not known to have been attributed to the sun in any such traditions. It must also be conceded that Joshua could only meaningfully have issued his directive to the moon before its realisation, not as it was already being executed, but it would beggar belief if the Israelites knew in advance that the sun becomes moon-like during solar eclipses. All that aside, the authors are seen to have and eat their second cake when they contend on one hand that Joshua was cognisant of the moon's invisibility on that day and on the other that he did perceive it in the sun's transformations during the eclipse.

Seventh, verse $12 \mathrm{~b}$ makes it clear that the sun and moon occupied different locations during the event - the sun above Gibeon and the moon above the Valley of Ayyalon. The two places are separated by a distance of about $15 \mathrm{~km}$. As was noted long ago, ${ }^{34}$ this arrangement is incompatible with a solar eclipse, when the sun and moon appear in the same place in the sky. To salvage his early interpretation of Joshua's solstitium as an eclipse, Barzilai proposed - at the expense of geographical feasibility - that 'Gabaon e la valle di Ajalon sono due

province d'Oran, 29 [1909]: p. 438) and the Kel Ahaggar, a Tuareg confederation (Maurice Benhazera, Six Mois chez les Touareg du Ahaggar [Algiers: Adolphe Jourdan, 1908], p. 63). The confusion partly boils down to arbitrary intellection: does the dark segment 'eat' the bright one, because the latter shrinks, or vice versa, because the latter develops a maw-like shape and increasingly 'contains' the former?

${ }^{32}$ Humphreys \& Waddington, 'Solar Eclipse': pp. 41, 42 Figure 4.

33 Marinus Anthony van der Sluijs, Traditional Cosmology; The Global Mythology of Cosmic Creation and Destruction, vol. 5: Solar and Lunar Anomalies (Vancouver, Canada: All-Round Publications, 2018), pp. 151-177.

${ }^{34}$ Smythe Palmer, Misunderstood Miracle, p. 46 note; John H. Walton, 'Joshua 10: 12-15 and Mesopotamian Celestial Omen Texts', in Alan Ralph Millard, James Karl Hoffmeier \& David Weston Baker (eds.), Faith, Tradition, and History; Old Testament Historiography in its Near Eastern Context (Winona Lake, Indiana: Eisenbrauns, 1994), p. 187. 
34 Joshua's Celestial Miracle was not an Eclipse: the Long and the Short

diverse espressioni usate, in sostanza, ad indicare un solo e medesimo sito. ${ }^{35}$ Instead, the usual understanding is that Joshua was situated inbetween the two sites, with the sun appearing low to the east and the moon low to the west, implying that the event transpired at early or midmorning and the moon was full or in its waning gibbous phase. ${ }^{36}$ While this is closer to the plain meaning of the text, the commentators' lack of astronomical expertise is palpable. If the date fell - as argued - not too long after the spring equinox, if Gibeon was correctly located at the Arabic settlement of Al Jib and if the Valley of Ayyalon was the BethHoron Pass, ${ }^{37}$ which lies somewhat to the northwest thereof, astronomical considerations show that the sun and moon can only have appeared above the two specified locations if the sun was close to the zenith, so that the Israelite leader must have invoked it at noon from Gibeon itself:

... Joshua's observation was made at Gibeon itself, almost precisely at the moment of noon ... The sun's declination must have been about $20^{\circ}$ north; probably, if anything, a little more. The sun rose therefore almost exactly at five in the morning ... The moon had not yet passed her third quarter, but was very near it; that is to say, she was about half full. Her declination did not differ greatly from $16^{\circ}$ north; she was probably about $5^{\circ}$ above the horizon, and was due to set in about half an hour. She had risen soon after eleven o'clock the previous evening, and had lighted the Israelites during more than half of their night march up from Gilgal. $^{38}$

\footnotetext{
${ }^{35}$ Barzilai, Errore, p. 5, citing Isaiah 28. 21 (falsely given as 33. 21) in support.

${ }^{36}$ Dozeman, Joshua, pp. 442-443; van Bekkum, From Conquest to Coexistence, pp. 283-284; Day, Yahweh, p. 154; Kenneth Lawson Younger, Ancient Conquest Accounts; A Study in Ancient Near Eastern and Biblical History Writing ('Journal for the Study of the Old Testament Supplement Series', 98; Sheffield: Sheffield Academic Press, 1990), pp. 313-314 note 43; Robert G. Boling, Joshua; A New Translation with Notes and Commentary ('The Anchor Bible', 6; Garden City, New York: Doubleday \& Company, 1982), pp. 284-285, 288; Eisler, 'Joshua and the Sun': p. 82; Maunder, Astronomy of the Bible, pp. 360361; 'Misinterpreted Miracle': pp. 360-361; Holzinger, Das Buch Josua, p. 40; Smythe Palmer, Misunderstood Miracle, pp. 32-33; Edersheim, Israel, p. 81.

${ }^{37}$ e.g., Boling, Joshua, p. 281; Holzinger, Das Buch Josua, pp. 39-40.

38 Maunder, Astronomy of the Bible, p. 365, cf. 361-364; 'Misinterpreted Miracle': pp. 361-364. Holzinger (Das Buch Josua, p. 40), followed by Eisler
} 
The sun would have been within $10^{\circ}$ or $12^{\circ}$ from the zenith, in perfect agreement with the text's placement of it in the 'middle' of the sky (verse 13b). Put differently, the early-morning condition is astronomically impossible for the given topography and time of year: 'The day of the year which would be indicated by the sun rising over Gibeon whilst the moon was setting in the valley of Aijalon would be about October 30, of our present calendar. ... or about February 12.,39

Based on a comparison with technical terminology employed in Mesopotamian omen literature, Walton supposed that Joshua was praying for an astrological opposition which would have been unfavourable for his opponents, i.e., a full moon seen at sunrise after the 14th day of the lunar month. ${ }^{40}$ Resourceful though this angle may be, Maunder's robust analysis rules out that the sun and moon could have appeared in opposition above Gibeon and the Valley of Ayyalon in the given season. In the northern hemisphere, the sun rises north of east in spring and summer, so that a full moon can then only be seen south of west; from the perspective of Gibeon, this would be away from the Valley of Ayyalon. This is not to mention other problems with Walton's thesis, such as the unlikelihood that the Israelites or Canaanites of this period were versed in the intricacies of Babylonian divination ${ }^{41}$ and the special pleading involved in reading 'before' instead of 'until' (verse 13a), understanding the 'middle of the sky' (verse 13b) as the 'half' (hăși) in which the sun appeared $^{42}$ and claiming that a full moon seen on the auspicious day would make for a 'full day' (verse 13b). ${ }^{43}$

Finally, if the interruption of the sun's usual pattern of behaviour consisted in an eclipse, the shower of hailstones on the same day would be reduced to coincidence. ${ }^{44}$ This observation is not damning, but might as well be taken on board.

In the light of these objections, Humphreys \& Waddington's eclipse hypothesis makes a mockery of the actual text and must be rejected.

As an aside, the historical reliability of the Biblical report is challenged by the observation that, far from it being 'a great city' ('îr gədōlā), as

('Joshua and the Sun': p. 82), embarrassingly asserted that the moon is never visible at noon; it often is, on days around its third and first quarter.

${ }^{39}$ Maunder, 'Misinterpreted Miracle': p. 362.

${ }^{40}$ Walton, 'Joshua 10 '.

${ }^{41}$ van Bekkum, From Conquest to Coexistence, p. 282.

${ }^{42}$ also suggested in Wilson, 'What Does “The Sun Stood Still' Mean?”: p. 47.

${ }^{43}$ See also the objections listed in Younger, Ancient Conquest Accounts, p. 214.

${ }^{44}$ Smythe Palmer, Misunderstood Miracle, p. 39. 
36 Joshua's Celestial Miracle was not an Eclipse: the Long and the Short

according to verse 2, archaeological excavations showed that 'Gibeon was not a city in the Late Bronze Age', ${ }^{45}$ although the excavator maintained an air of optimism. ${ }^{46}$ An anonymous reviewer of an earlier version of this article realised that this throws another spanner in Humphreys \& Waddington's works, as dating events in a text which errs so spectacularly on fundamental facts seems rather pointless, no matter how precise the astronomical calculations might be. However, the chronology of the ancient Near East is far from settled. Bimson proposed that, on a conventional late 15th-century date, Joshua's subjugation of Gibeon and other cities actually corresponds to the end of the Levantine Middle Bronze Age II. ${ }^{47}$ At that time Gibeon was a substantial city with finely made pottery: 'This seems to have been not only a time of general prosperity but one in which the arts and crafts flourished with a freshness and originality that had been introduced into Palestine by the arrival of a singularly creative group, ${ }^{48}$ presumably the Hyksos. Bimson's revision is consistent with the system later promoted by James' group, although the specific problem of Joshua's Gibeon is not mentioned in the latter's flagship publication. ${ }^{49}$ Even if the Israelite takeover of Gibeon was a 14th-century event, its assignment to the end of the Middle Bronze Age would solve the archaeological conundrum.

\section{A Cross-cultural Perspective}

In the preceding discussion, the explanation of Joshua's astronomical marvel as an eclipse was refuted with arguments formulated within the same theoretical framework as that adhered to by Humphreys \& Waddington - one in which the literal accuracy of the text is taken for granted, provided that the words are correctly interpreted. Far more

\footnotetext{
${ }^{45}$ Dozeman, Joshua, p. 401.

${ }^{46}$ James Bennett Pritchard, Gibeon; Where the Sun Stood Still; The Discovery of the Biblical City (Princeton, New Jersey: Princeton University Press, 1962), pp. 135-137, 157-158.

${ }^{47}$ John James Bimson, 'The Conquest of Canaan and the Revised Chronology', Society for Interdisciplinary Studies Review, 1.3 (1976), 2-7, 32; Redating the Exodus and Conquest ('Journal for the Study of the Old Testament Supplement Series', 5; Sheffield: The University of Sheffield, 1978), pp. 33, 52, 61, 205-206, 231, 244, 278.

${ }^{48}$ Pritchard, Gibeon, pp. 134-135, cf. 113, 125, 133, 154-156.

49 Peter James, I. J. [Nick] Thorpe, Nikos Kokkinos, Robert Morkot \& John Frankish, Centuries of Darkness (London: Jonathan Cape, 1991), but see pp. 164, 168, 195 Table 8: 3, 368 note 4.
} 
commendable is a meta-analysis superseding such rigorous acceptance of the 'received tradition'. A study of the Hebrew folktale can scarcely hope to succeed while ignoring the dimension of comparative mythology and ritual, especially if an origin is sought in some natural phenomenon which could have been recorded in other cultures, too. Certainly, the unfortunate legacy of pan-Babylonists, creationists and a host of pseudoscholars with a cavalier attitude to intercultural parallels has brought the comparative approach into disrepute, yet much is to be gained from an investigation of similar traditional records and practices from cultures both near and far - so long as no hasty assumptions are made that such traditions relate to identical natural conditions, let alone a single event or diffused tradition.

Scholars have often commented on the remarkable similarity between mythological ideas from very different parts of the world. Themes transcending known cultural boundaries include such globally attested tendencies as the presentation of lightning or the rainbow as a serpent and the conviction that the spots on the moon resulted from the transportation thither of some hapless person. To simply admit the existence of such classes of widespread motifs, whether expressed in myth or ritual, does not in itself carry any implication of a shared origin in a singular cause or place, but potentially helps to suggest a credible naturalistic context for some instances. Affording a glimpse of an archaic worldview which is mostly alien to the modern mind, the motif analysis is just a tool which may or may not assist in elucidating the 'nature' of a tale, by providing some sense of geographic and chronological distribution and by allowing cautious extrapolation of explicit information supplied in some cases to ones in which it is lacking. For example, the well-established fact that some cultures conceived of the thunderbolt as a serpent justifies a hypothetical possibility - but in itself does not prove - that aerial snakes of other traditions could be based on the same natural phenomenon. Respecting the present problem, an eclipse interpretation of the story of Joshua could have benefitted from the citation of incontrovertible instances from unrelated cultures of eclipses conceptualised as a sudden staying of the sun or moon. Such traditions do not appear to be in evidence.

In addition to the Near Eastern omen literature already twice referenced above, one obvious instructive frame of reference for Joshua's celestially facilitated victory over the Amorites is the motif of divine intervention in war, often by means of dramatic stellar or meteorological agents, such as comets, bolides, meteorites, thunderstorms, hail and an 
38 Joshua's Celestial Miracle was not an Eclipse: the Long and the Short

abnormal darkness descending over the battlefield. This theme was prominent in ancient Near Eastern settings and has received ample scholarly attention, including its application to the Biblical saga of the Israelite Exodus and conquest. ${ }^{50}$ More broadly, it appears that the conquest narratives in Joshua and from other ancient Near Eastern cultures shared a literary transmission code and thematic parallels extending to such details as an all-night march, giving chase following the battle and concentration of military prowess in one single day; the latter claim was often unquestionably hyperbolic. ${ }^{51}$

Joshua's specific stratagem of detaining the sun and moon, too, finds a match in unambiguous parallels outside Palestine, but this connection has been understudied. ${ }^{52}$ As it happens, a rich vein of myths and rituals concerns a time - short or long - when the sun or moon moved at a different speed, not at all or in the opposite direction, in the sun's case

50 e.g., Dozeman, Joshua, pp. 440-441, 447, 449-450; van Bekkum, From Conquest to Coexistence, pp. 273-297; Younger, Ancient Conquest Accounts, pp. 210-220; Kang, Divine War; Weinfeld, 'Divine Intervention'; Harry Angier Hoffner, 'Histories and Historians of the Ancient Near East: The Hittites', Orientalia, new series, 49. 4 (1980): pp. 314-317, 326-328 (for Hittite culture); Félix-Marie Abel, 'Les Stratagèmes dans le livre de Josué', Revue Biblique, 56. 3 (1949): pp. 333-334; Johannes Friedrich, 'Himmelszeichen in ägyptischen und hethitischen Kriegsberichten', Orientalistische Literaturzeitung, 39 . 3 (1936): p. 138. For the darkness, see especially Martin Litchfield West, Indo-European Poetry and Myth (Oxford: Oxford University Press, 2007), pp. 480-481; The East Face of Helicon; West Asiatic Elements in Greek Poetry and Myth (Oxford: Clarendon Press, 1997), pp. 212-213; Smythe Palmer, Misunderstood Miracle, pp. 43-50, 92 note U.

${ }^{51}$ Younger, Ancient Conquest Accounts, pp. 195-237, especially p. 207 (march), pp. 208-211 (chase) and pp. 215-217, 219 (concentration in one day; $c f$. van Bekkum, From Conquest to Coexistence, p. 294).

${ }^{52}$ In 1 Chronicles 4. 22, the Vulgate (ed. Tvveedale, Biblia Sacra, p. 234, tr. Edgar, Vulgate Bible, vol. 2B ['Dumbarton Oaks Medieval Library', 5; Cambridge, Massachusetts: Harvard University Press, 2011], p. 1147) reads 'he that made the sun to stand' (qui stare fecit solem) where the Masoretic text (eds. Elliger et al., Biblia Hebraica, p. 1466) has yōqìm, generally held to be the name of a person. Jan Carel Matthes ('Das Solstitium Jos $10^{12-14}$, Zeitschrift für die alttestamentliche Wissenschaft, 29. 4 [1909]: p. 265) recognised a Moabite counterpart to Joshua in this lection, but the text clearly deals with descendants of Judah. The Vulgate variant is most likely an error arising from the

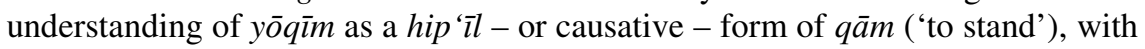
interpolation of a word for 'sun'; compare Eisler, 'Joshua and the Sun': p. 80 note 4; Smythe Palmer, Misunderstood Miracle, p. 60 note 1.

Culture and Cosmos 
with concomitant variation in the length of day. ${ }^{53}$ The mythological repository includes accounts of the sun's retardation at the hands of a legendary terrestrial hero. Pride of place in this class goes to traditions concerning the snaring of the sun, typically with an eye to punishing it for its excessive heat, as in most North American versions, or lowering its speed permanently, as ubiquitously told throughout eastern Polynesia and on Samoa, with Maui for protagonist. ${ }^{54}$ The imagery recalls the 'shackling' of the cited lines from Ecclesiasticus.

Especially early commentators on the story of Joshua had an inkling of this comparative-mythological background, be it in the form of traditions consistent with the Biblical one as if representing the same event, which they believed to be historical, ${ }^{55}$ or, more cautiously, mere global parallels

${ }^{53}$ e.g., Marinus Anthony van der Sluijs, review of Luigi Piccardi \& William Bruce Masse (eds.), Myth and Geology ('Geological Society Special Publication', 273; London: Geological Society, 2007), in Myth \& Symbol, 5. 2 (2009), p. 66; Traditional Cosmology, pp. 41-62, 81-96, 233-244. From a prescientific point of view, oblivious to the earth's rotation around a tilted axis, the sun's speed is variable, being higher in winter, when the hours of daylight are shorter, and lower in summer, when they are longer, while the sun covers the same daily distance from east to west.

${ }^{54}$ Examples are too numerous to cite, but an excellent place to start is Katharine Luomala, Oceanic, American Indian, and African Myths of Snaring the Sun ('Bernice P. Bishop Museum Bulletin', 168; Honolulu, Hawai ‘i: 1940).

${ }^{5}$ e.g., Petrus Danielus Huetius, Alnetance Qucestiones de Concordia Rationis et Fidei (Caen: Joannes Cavelier, 1690), p. 229; Louis-Athanase Chaubard, Élémens de géologie mis a la portée de tout le monde, et offrant la concordance des faits géologiques avec les faits historiques, tels qu'ils se trouvent dans la Bible, les traditions Égyptiennes et les fables de la Grèce (Paris: Risler, 1833), pp. 288-290, 297; Edward Greswell, Fasti Temporis Catholici and Origines Kalendaria, vol. 1 (Oxford: Oxford University Press, 1852), pp. 324-343, 373374; Three Witnesses, pp. 117-119; Smythe Palmer, Misunderstood Miracle, pp. 95 note Y, 117; Immanuel Velikovsky, Worlds in Collision (New York: The MacMillan Company, 1950), pp. 45-46. Frédéric de Rougemont (Le Peuple primitif; Sa religion; son histoire et sa civilisation, part 1: Religion, vol. 2 [Geneva: Joël Cherbuliez, 1855], p. 273, cf. 272, 547-548) tentatively connected the two North American variants of the sun-snaring myth which he knew to 'la suspension du mouvement de rotation de la terre au temps de Josuë', arguing that they erred in dating the episode to directly after the deluge; unfortunately, he misattributed the myths: his Chipewyan one is actually Tłıchọ (John Franklin, Narrative of a Second Expedition to the Shores of the Polar Sea, in the Years 1825, 1826, and 1827; Including an Account of the Progress of a Detachment to the Eastward by John Richardson [Philadelphia, Pennsylvania: Carey, Lea, and 
40 Joshua's Celestial Miracle was not an Eclipse: the Long and the Short

indicative of separate events of a similar nature, if not folklore pure and simple without any realistic basis. ${ }^{56}$ Wary of the utility or validity of a comparative approach, recent exegetes expended little effort in collecting additional data within these mythological categories of 'solar anomalies'. The pickings are rich for those prepared to look, however; some of the tales and rituals even centre on a legendary battle, like that of Joshua.

As often noted by others, though sometimes downplayed, ${ }^{57}$ a close Greek analogue to Joshua's motionless sun is a scene in the Iliad in which Agamemnon implores Zeus not to let the sun set before the Greeks have triumphed over the Trojans:

$\ldots$ and in prayer lord Agamemnon spoke among them, saying: 'Zeus, most glorious, most great, lord of the dark clouds, who dwell in the sky, let not the sun go down, nor darkness come on us, until I have cast down headlong Priam's halls, blackened with smoke, and have burned its gates with consuming fire, and split Hector's tunic about his

Carey, 1828], pp. 241-243) and his Wyandot one, also so identified by Henry Rowe Schoolcraft (Information Respecting the History, Condition and Prospects of the Indian Tribes of the United States: Collected and Prepared under the Direction of the Bureau of Indian Affairs, Per Act of Congress of March 30, 1847, vol. 3 ['Ethnological Researches, Respecting the Red Man of America'; Philadelphia, Pennsylvania: Lippincott, Grambo \& Company, 1853], p. 320), is really Innu (Paul le Ieune, Relation de ce qvi s'est passé en la Novvelle France en l'annee 1637 [Rouen: Iean le Bovllenger, 1638], pp. 174-175).

${ }^{56}$ e.g., Edmond de Bovis, 'De la Société Tahitienne à l'arrivée des Européens', Revue Coloniale, series 2, 14 (1855): pp. 513 note 1, 515, who recognised Maui as a 'Josué tahitien'; Matthes, 'Solstitium': pp. 264-265; Eisler, 'Joshua and the Sun': p. 80; Luomala, Oceanic, American Indian, and African Myths, p. 43; Theodor Herzl Gaster, Myth, Legend, and Custom in the Old Testament; A Comparative Study with Chapters from Sir James G. Frazer's Folklore in the Old Testament (New York and Evanston: Harper \& Row, 1969), pp. 414-415.

57 e.g., Dozeman, Joshua, p. 445; van Bekkum, From Conquest to Coexistence, pp. 292-293; West, East Face, p. 357; Younger, Ancient Conquest Accounts, p. 215; Kang, Divine War, p. 158; Weinfeld, 'Divine Intervention', p. 147; Boling, Joshua, pp. 287-288; Soggin, Joshua, p. 122; Gaster, Myth, p. 414; Abel, 'Stratagèmes': pp. 334-335; Eisler, 'Joshua and the Sun': p. 80; Matthes, 'Solstitium': p. 264; Max Krenkel, 'Biblische Parallelen zu Homeros', Jahrbücher für classische Philologie, 34 = Neue Jahrbücher für Philologie und Paedagogik, 58. 137 (1888): p. 19.

Culture and Cosmos 
breast, tattered by the bronze ...' So he spoke; but not yet would the son of Cronos grant him fulfillment ... 58

Unlike in the Hebrew legend, the moon does not participate, the prolongation of the day is not claimed to have come to pass and the text does not spell out in what way Agamemnon's wish would have been realised - by an arrest, a deceleration or a reversal of the sun, or a combination of these.

Other parallels, by contrast, were apparently never spotted before. Some of these, like the Homeric passage, hailed from cultural regions which were or may have been in contact with the Levant at one time or another, directly or indirectly, and perhaps exchanged folklore with it. In the ancient Egyptian Book of the Dead, the serpent on the mountain of the west causes a stoppage of the celestial boat of Re, the sun god. ${ }^{59}$ A myth tells how the child Horus, while in hiding from his brother and foe Set, is hurt by the bite or sting of a venomous creature and the goddess Selqet orders Re to bring his boat to a standstill, enabling Thoth - perhaps as the moon god - to cure the babe with his magic; all of nature suffers and darkness prevails until the sun god resumes his course. ${ }^{60}$ The possibility cannot be excluded that this story existed as early as the 2nd millennium BCE and the Hebrews who had just fled from Egypt were familiar with it; although it is set in a distant, mythical past, the Hebrew literary tendency to conflate events surrounding the Exodus with cosmogonic traditions is well known.

\footnotetext{
${ }^{58}$ Homer, Iliad, 2. 411-420, tr. Augustus Taber Murray, Homer: Iliad, vol. 1: Books 1-12 ('Loeb Classical Library', 170; Cambridge, Massachusetts: Harvard University Press, $1999^{2}$ ), pp. 90-93. Compare Hera's hastening of sunset in 18. 239-242, Athena's delaying of dawn in Odyssey, 23. 241-246 and the comments in Mark W. Edwards, Books 17-20 ('The Iliad: A Commentary', 5; Cambridge: Cambridge University Press, 1991), p. 174.

${ }^{59}$ Book of the Dead, 108, repeated in Coffin Texts, 160 (II 380-386).

${ }^{60}$ Socle Béhague (Leiden F 1950/8. 2; mid- or late 1st millennium BCE), 4 (e 3 f 39), tr. Adolf Klasens, A Magical Statue Base (Socle Behague) in the Museum of Antiquities at Leiden (doctoral dissertation; 'Oudheidkundige Mededelingen uit het Rijksmuseum van Oudheden te Leiden', 33; Leiden: E. J. Brill, 1952), pp. 55-58, cf. 81-96, 106-107; Metternich Stela, 14 (204-251), tr. Constantin Emil Sander-Hansen, Die Texte der Metternichstele ('Analecta Aegyptiaca Consilio Instituti Aegyptologici Hafniensis Edita', 7; Copenhagen: Ejnar Munksgaard, 1956), pp. 71-73.
} 
Intriguingly, the myth of Horus' illness and its consequences for the sun enjoyed a vivid Nachleben in the realm of Coptic magic, with a rôle allocated to the moon. An example is this charm:

Look, Horus the son of Isis was in distress. She is (?) far from him ..., since she turned to the sun, (she) turned to the moon, to confine them (?) in the middle of heaven, to the Pleiades, in the middle of heaven. ${ }^{61}$

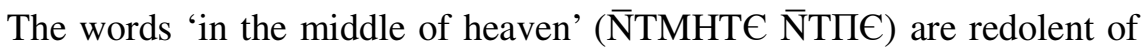
the identical phrase (bahăși haššămayim) in the story of Joshua (verse 13b). Other Coptic spells repurposed the detention of the luminaries as a threat issued by the magician to spiritual entities in his service, such as the archangels: 'But if you do not obey my mouth or perform the things of my hands, I shall turn my face to the east and obstruct the sun in the east (and) the moon in the west. ${ }^{62}$ Alternatively, some spells cast this disturbance of the natural order as a promise or a fait accompli by the demon dedicated to the sorcerer. The infernal demon Tartarouchos thus pledges: 'If she does not come to me, I shall stop the sun in its chariot, the moon in its course, the crown of stars upon the head of Jesus ...63 Comparison of the respective variants suggests the underlying image of the sun inactive in the east, the moon in the west and either the Pleiades

${ }^{61}$ MS. Berlin 5565 (probably from Thebes), lines 7-8, ed. Walter Beltz, 'Die koptischen Zauberpapyri der Papyrus-Sammlung der Staatlichen Museen zu Berlin', Archiv für Papyrusforschung und verwandte Gebiete, 29 (1983): p. 62, tr. Marvin Meyer, in Marvin Meyer \& Richard Smith, Ancient Christian Magic; Coptic Texts of Ritual Power (New York: HarperCollins, 1994), p. 93 \#47. Instead of 'to confine them', Beltz ('Die koptischen Zauberpapyri': p. 62) translated 'um sie zu bergen' and Angelicus M. Kropp 'um sie in Gewahrsam zu bringen' (Ausgewählte koptische Zaubertexte, vol. 2: Übersetzungen und Anmerkungen [Brussels: Édition de la Fondation Égyptologique Reine Élisabeth, 1931], p. 13), but also 'um sie ... aufzuhalten' (vol. 3: Einleitung in koptische Zaubertexte [Brussels: Édition de la Fondation Égyptologique Reine Élisabeth, 1930], p. 144).

${ }^{62}$ London Oriental Manuscript 6794, lines 19-21, tr. Smith, in Meyer \& Smith, Ancient Christian Magic, p. 279 \#129, compare 232 \#116.

${ }^{63}$ MS. Berlin 8314, lines 27-29, tr. Meyer, in Meyer \& Smith, Ancient Christian Magic, p. 160 \#75; cf. Kropp, Zaubertexte, vol. 2, p. 23. Compare Meyer \& Smith, Ancient Christian Magic, pp. 249 \#123 (where the amulet is attributed to Isis), 269 \#127; and the discussion in Kropp, Zaubertexte, vol. 3, pp. 141-145. Note the classical influence in seating the sun in a chariot instead of a barge.

Culture and Cosmos 
or a 'fire' - perhaps the constellation of Ursa Major? - in the 'middle' of the sky. This sustained dawn is somewhat reminiscent of the distribution of the sun and moon at opposite sides of the sky on Joshua's exceptional day, as far as permitted by Maunder's astronomical calculations. At any rate, it signals a symbolic return to the cosmic creation; in the charm last cited above one can see 'an ancient Egyptian ritual form whereby the priest declared the power to return the cosmos to primal chaos if an act were not completed. ${ }^{64}$ Another comparandum is: 'Sonne, werde nicht rot, / Mond, gehe nicht auf ..., ${ }^{65}$

The same type of magical Drohung surfaces in the Greek magical papyri (1st century BCE to 5th century $\mathrm{CE})$ :

... [the sun] will stand still; and should I order the moon, it will come down; and should I wish to delay the day, the night will remain for me; and should / we in turn ask for day, the light will not depart ...66

If I say it complete, there will be an earthquake, the sun will stop and the moon will be afraid and the rocks and the mountains and the sea and the rivers / and every liquid will be petrified; the whole cosmos will be thrown into confusion. ${ }^{67}$

Relying on information from Chaeremon of Alexandria (1st century CE), Porphyry of Tyre (c234-c305) rebuked an Egyptian priest called Anebo (Anubis) for such practice: 'But much more absurd than this is the notion that a man under the power of any ordinary master should employ threats ... to the royal Sun himself, or the Moon, or any of the deities in heaven, and try to frighten them by lies, in order that they may speak the truth. For to say that he will batter the heavens, and publish the secrets of Isis, and show the forbidden mystery at Abydos, and stop the sacred boat, and scatter the limbs of Osiris for Typhon, - is not this the last excess of

${ }^{64}$ Meyer \& Smith, Ancient Christian Magic, p. 150.

${ }^{65}$ British Museum (London), Anastasi Collection, 29528, recto, lines 5-6, tr. Kropp, Zaubertexte, vol. 2, p. 66; Harry Reginald Hall (Coptic and Greek Texts of the Christian Period from Ostraka, Stelae, etc. in the British Museum [London: British Museum, 1905], p. 149 \#27) translated: 'Sun, do not set; Moon, do not rise', but the sun's reddening could very well refer to its rising.

${ }^{66}$ Greek Magical Papyri, 34. 1-6, tr. Hans Dieter Betz, The Greek Magical Papyri in Translation; Including the Demotic Spells (Chicago: University of Chicago Press, $1992^{2}$ [1986]), p. 267.

${ }^{67}$ Greek Magical Papyri, 13. 873-876, tr. Betz, Greek Magical Papyri, p. 192. 
44 Joshua's Celestial Miracle was not an Eclipse: the Long and the Short

stupidity on the part of him who threatens things of which he has neither knowledge nor power ...? ${ }^{68}$ Joshua's adjuration of the sun and moon can be seen as a very early exponent of the same type of magic which in Egypt developed into this syncretistic witchcraft, blending notions from ancient Egyptian and Christian religion together.

In the Egyptian myth of Horus' disease, it is unclear why the sun's arrest resulted in darkness. A similar puzzle is presented by many North American and west African variants of the sun-snaring myth ${ }^{69}$ and by comparison of a few Sumerian passages about Utu, the sun god, and Nanna, the moon god. Though much older than the Coptic spells, these latter, too, are of a magical nature: Bound Utu at the horizon, bound Nanna at the height of
heaven ...

${ }^{68}$ Porphyry, Letter to Anebo, Fr. 64. 3-4, in Eusebius, Preparation for the Gospel (Praeparatio Evangelica), 5. 10 (198a-b), eds. Henri Dominique Saffrey \& Alain-Philippe Segonds, Porphyre; Lettre à Anébon l'Égyptien ('Collection des Universités de France'; Paris: Les Belles Lettres, 2012), p. 42, tr. Edwin Hamilton Gifford, Preparation for the Gospel; Eusebius, vol. 1: Books 1-9 (Grand Rapids, Michigan: Baker Book House, 1903), p. 216. The word translated as 'sacred boat' is barin (accusative).

${ }^{69}$ See, conveniently, Luomala, Oceanic, American Indian, and African Myths, pp. 7 \#2-\#4, 8 \#7-\#8, \#10, \#12-\#13, \#16, 9 \#22-\#23, 10, 44 \#1-\#2, 45 \#7, \#9. A more recently recorded Ojibwe myth links the sun's fixity to light instead of darkness: 'Waubun (Dawn) and Ningobianong (Star Sinking in Waters or Evening) began their duel. Both were very powerful medicinemen possessing and controlling vast knowledge and potent medicines.... Waubun, young, proud, and strong announced, "I shall stop the sun in the eastern sky so that it will always be morning." As he wished the sun stopped. The Anishnabeg were amazed and glad. For a long time the sun remained unmoving.' (Basil Johnston, Ojibway Heritage [Toronto: McClelland and Stewart, 1976], p. 30) This is a creation myth, insofar as the sun initiates its pattern of setting and rising in the remainder; 'Anishnabeg' is the Ojibwe's endonym.

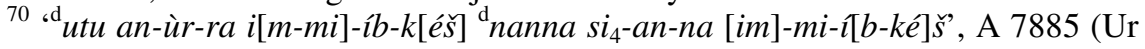
III period -21 st century BCE), recto, lines 7-8 = verso, lines 16-17, tr. Janice Polonsky, The Rise of the Sun God and the Determination of Destiny in Ancient Mesopotamia (doctoral dissertation; Philadelphia, Pennsylvania: University of Pennsylvania, 2002), p. 185 note 517. These lines attribute the binding to the demon Samana, but are absent from the later bilingual incantations against Samana - Irving Leonard Finkel, 'A Study in Scarlet: Incantations against Samana', in Stefan Mario Maul (ed.), Festschrift für Rykle Borger zu seinem 65.

Culture and Cosmos 
Utu lay down upon the horizon, Nanna ceased to be in the height of heaven ... ${ }^{71}$

The sun darkens on the horizon, the moon becomes extinguished in the heights of heaven ... ${ }^{72}$

Apparently, having 'the sun god at the horizon and the moon at the sky's zenith' was a literary commonplace. ${ }^{73}$ In unison, the variations on the theme seem to suggest that the 'binding' (kéš) entailed an irregular obscuration of the sun and moon - if not the entire firmament - at sunrise or sunset with the moon at its highest point, a condition requiring that it be gibbous or crescentic. Was there an ancient Near Eastern or even more widespread belief that the luminaries only shine when moving? ${ }^{74}$ Some Assyriologists surmised that the Babylonians believed the wind to rekindle the sun every morning as if fanning a smouldering ember. ${ }^{75}$ If the sun was further held to be propelled on its course by the wind, in keeping with the nautical image of a solar boat, it follows that - on such a belief system - abatement of the wind could cause the sun to slow down and dim at once. Against such conjecture, a Sumerian balag lamentation (1st millennium BCE) paints a picture of a complex disaster in which the

Geburtstag am 24. Mai 1994; Tikip Santakki mala Bašmu ('Cuneiform Monographs', 10; Groningen: Styx Publications, 1998), pp. 92-93. Finkel (p. 83) read $s i_{4}$-an-na more literally as 'in the red (evening) sky (?)'. Polonsky's translation is supported by the unambiguous terms for 'zenith' an-pa and si-unna used in the other passages which she cited; compare Wayne Horowitz, Mesopotamian Cosmic Geography ('Mesopotamian Civilizations', 8; Winona Lake, Indiana: Eisenbrauns, 1998), pp. 233-234, 237-238; Mark Glenn Hall, A Study of the Sumerian Moon-God, Nanna/Suen (doctoral dissertation; Philadelphia, Pennsylvania: University of Pennsylvania, 1985), pp. 694-695.

71 'dutu an-úr-ra ba-da-ná d nanna an-pa-šè múš ba-an-da-ni-íb-ga', tr. Polonsky, Rise of the Sun God, p. 185 note 517.

72 'd utu an-úr-ra ba-da-šú-ru ${ }^{\mathrm{d}}$ nanna an-pa-šè ba-da-gir ${ }_{5}$ ' = '( $\left.{ }^{\mathrm{d}} \mathrm{MIN}\right)$ ina $i$-šid AN-e i-te-ru-ub ( $\left.{ }^{\mathrm{d}} \mathrm{MIN}\right)$ ina e-lat AN-e ir-ta-bi', tr. Polonsky, Rise of the Sun God, p. 185 note 517.

${ }^{73}$ Polonsky, Rise of the Sun God, p. 185 note 517.

${ }^{74}$ Compare the comments in Smythe Palmer, Misunderstood Miracle, pp. 37-38.

${ }^{75}$ Wolfgang Heimpel, 'The Sun at Night and the Doors of Heaven in Babylonian Texts', Journal of Cuneiform Studies, 38. 2 (1986): pp. 142, 148-151; Christopher Woods, 'At the Edge of the World: Cosmological Conceptions of the Eastern Horizon in Mesopotamia', Journal of Ancient Near Eastern Religions, 9.2 (2009): p. 198. 
46 Joshua's Celestial Miracle was not an Eclipse: the Long and the Short

obstruction and consequent fading of the sun and moon appear alongside a storm and earthquakes:

The heavens continually rumbled, the earth continually shook.

The sun lay at the horizon.

The moon stopped still in the midst of the sky.

In the sky the great lights disappeared.

An evil storm ... the nation.

A deluge swept over the lands. ${ }^{76}$

The joint occurrence of these calamities reminds of the concurrency of a hailstorm and the solar and lunar aberrations during Joshua's routing of the Amorites. Such a scenario of atmospheric darkening stylistically expressed as a pausing of sun and moon would shed a different light on the Joshua story and perhaps swing the balance in favour of a foreshortened day caused by something other than an eclipse, despite the undivided opinion of the earliest paraphrases and translations that the day was lengthened. ${ }^{77}$

The Abzakh tribe of the Adyghe (Cherkessia, North Caucasus) passed on a tale in which the sun acquires its habit to pause on the horizon at sunset following a request made by Setenaya, matriarch of the Narts:

Have you seen how as evening approaches the sun pauses in its course for just a moment at the horizon, on the sky's lower flank, just before it sets? I shall tell you why this is so. One day, long ago, Setenaya and a lad of the Narts, who made harnesses, decided to compete against one another in traditional skills. ... As the day passed, they sat, each laboring at their separate tasks. The Nart youth was an experienced craftsman. He finished his saddle and rested. As the sun approached the horizon, there remained for Setenaya just a little more work than she could finish. 'O, Sun!' she pleaded. 'If only you would halt a while!' In the time of the

${ }^{76} U_{4}$-dam Gù-dé-dé-aš (He is a Storm, at the Howling), lines 10-15, ed. and tr. Mark E. Cohen, The Canonical Lamentations of Ancient Mesopotamia, vol. 1 (Potomac, Maryland: Capital Decisions Limited, 1988), pp. 429, 435-436. In line with the preceding discussion, an-pa-šè (line 12) can be more accurately translated as 'in the zenith of the sky'.

77 Walton ('Joshua 10', p. 190) cited this lamentation in his discussion of Joshua's prayer as an astrological omen, but gave short shrift to its possible basis in real events.

Culture and Cosmos 
Narts wishes would come true. So the sun halted its descent for a little while and sat waiting at the edge of the earth until she had finished sewing. ... From that day forward, as evening approaches, the sun pauses in its course for a little while on the sky's lower flank. To do so has become part of its nature. ${ }^{78}$

Further, traditions about the sun's standstill seem to be akin to ones about a reversal in the direction of its movement - from west to east instead of east to west; both anomalies could result in an extension of daylight hours and the sun may briefly halt before it resumes its course in the opposite direction. ${ }^{79}$ The Persian writer Abū Ishạa Aḥmad ibn Muhammad al-Ta'labī (961-c1038 CE) retold the story of Joshua's battle with the Amorites as follows:

The battle was on a Friday, and a remnant was left of them when the sun was about to set and the night of the Sabbath would begin. Joshua feared that they would be impossible for him (to defeat). So he said: 'O my God! Return the sun to me!' Or he said to the sun: 'Verily you are obedient to God and I am obedient to God', and he asked the sun to stand still and the moon to remain, until he would take vengeance from the enemies of God before the setting of the sun. The sun returned for him and added a whole hour during the day until he slew all of them. ${ }^{80}$

\footnotetext{
${ }^{78}$ John Colarusso (tr.), Nart Sagas from the Caucasus; Myths and Legends from the Circassians, Abazas, Abkhaz, and Ubykhs (Princeton, New Jersey: Princeton University Press, 2002), pp. 49-50.

${ }^{79}$ Gaster (Myth, p. 528 note 12) compared the use of conjugated forms of dammam in the account of Joshua's solar miracle to 'the Arabic $d-w-m$, used specifically of the sun's turning in its course.' Unfortunately, he did not cite sources or examples. The usual meaning of this verb is 'to be constant, to persist, to continue, to remain, to last' as also 'to circle', Elsaid M. Badawi \& Muhammad Abdel Haleem (eds.), Arabic-English Dictionary of Qur'anic Usage ('Handbook of Oriental Studies', 1: 'The Near and Middle East', 85; Leiden: Brill, 2008), p. 319 s.v. ' $d-w-m$ '. Because of this and because - unlike planets - the sun is never seen to perform a retrograde movement, it is not at all clear what Gaster meant; if the sun's pursuit of its regular trajectory, then what would Joshua have asked of the sun?

${ }^{80}$ al-Ta 'lab̄i, 'Arā'is al-Majālis fì Qișaș al-Anbiyā' (The Brides of Sessions about the Tales of the Prophets), tr. William M. Brinner, 'Arā' is al-Majālis fī Qișaș alAnbiyā' or 'Lives of the Prophets' as Recounted by Abū Ishāa Ahmad ibn
}

Culture and Cosmos 
48 Joshua's Celestial Miracle was not an Eclipse: the Long and the Short

This passage gives two different versions of Joshua's request, one addressed to God and the other to the sun. While both are arguably faithful to the Biblical original, the use of the verbal form urdud (from $r$ $d-d$, 'to return') in the former, repeated in the final sentence (ruddat), ${ }^{81}$ demonstrates that the intention there was for the sun to literally turn back in an eastern direction. ${ }^{82}$ It would seem that al-Ta 'labī was conversant with a variant on the orthodox version of the story, illustrating a remarkable fluidity of tradition. ${ }^{83}$

Muhammad ibn Ibrāhìm al-Tha'labì ('Studies in Arabic Literature'; 'Supplements to the Journal of Arabic Literature', 24; Leiden: Brill, 2002), p. 411.

${ }^{81}$ Hasan M. El-Shamy, personal communication, 9 July 2018; Badawi \& Abdel Haleem, Arabic-English Dictionary, pp. 356-357 s.v. ' $r$-d-d'.

${ }^{82}$ Heribert Busse (Islamische Erzählungen von Propheten und Gottesmännern; Qiṣaș al-anbiyā' oder 'Arā'is al-mağālis von Abū Isḥāq Aḥmad b. Muhammad b. Ibrāhīm aț-Ta'labī; Übersetzt und kommentiert ['Diskurse der Arabistik', 9; Wiesbaden: Harrassowitz Verlag, 2006], p. 319) translated the first version of the request unambiguously, but the final sentence less literally, suggesting an act of holding back or restraining: 'Laß die Sonne zurückkehren! ... Da wurde die Sonne für ihn zurückgehalten und der Tag um eine Stunde verlängert ...'

${ }^{83}$ Reversal does not occur in the otherwise very similar account attributed to Abū Isḥāq Ka'b al-Aḥbār (d. c652 CE) by Abū Ja'far Muḥammad ibn 'Abdullāh al-Kisā' $\overline{1}$ in his Qișaș al-Anbiyā' (Tales of the Prophets; c. 1200 CE), 71, tr. Wheeler M. Thackston, The Tales of the Prophets of al-Kisa' $i$; Translated from the Arabic with Notes ('Library of Classical Arabic Literature', 2; Boston: Twayne Publishers, 1978), pp. 259-260: 'Joshua feared the sun would set before he had gained his objective (being the eve of the sabbath, fighting would then be forbidden). Yet there remained about one hour of daylight, or one 'lance'. (Wahb ibn Munabbih said that one 'lance' is a forty-year distance traveled by the sun and is equivalent to one hour of the day, since each day the sun travels from east to west the distance of six hundred years.) Then Joshua stretched forth his hand to the heavens and called upon his Lord, saying, '... Imprison the sun for us for the remainder of this battle that we may fight the people of Jericho.' And God commanded the angel who was entrusted with the sun to keep it in its sphere so that Joshua could finish the battle. They fought on until they had extinguished the giants from the face of the earth, and then the sun set. From that day forth the regulation of the stars has been confused.' The enemy's stronghold is here falsely identified as Jericho, while the hour is not additional but remaining; by how much the daylight was extended is not stated. Curiously, if the figures are correct the length of an ordinary day would have had to be 15 'hours', presumably in all seasons. The sun's 'sphere' surely refers to Platonic-Ptolemaic cosmology; just so, the 'wheel' in which the sun was supposed to move 
Clear-cut examples of solar retrogression are the Biblical 'sign of Hezekiah'; ${ }^{84}$ putative Egyptian reports of the sun having changed direction repeatedly; ${ }^{85}$ and the popular Greek myth of Helios' return towards the position of dawn at midday in the legendary time of Atreus and Thyestes, ${ }^{86}$ just prior to the Trojan War. Nyikang (Nikīàno) was a legendary king and ancestor, datable to $c 1200 \mathrm{CE}$, in the tradition of the Shilluk (southern Sudan). According to one story 'soll Nyikang im Streite mit den Bewohnern des Landes Canggaro die Sonne am Abend wieder aufsteigen gemacht haben, um so den Krieg zu seinen Gunsten vollenden zu können'; the action would have earned this African Joshua the title Atulecang ('der die Sonne aufsteigen macht'). ${ }^{87}$ Because the broader

according to al-Ta'labī ('Arā'is al-Majālis fì Qișas al-Anbiyā', tr. Brinner, 'Arā'is al-Majālis', p. 31) must be the great circle of the sun's sphere along which it orbits. Compare: 'You will find that the sun is kept within a sheath, that the sheath is set within a sphere', Midraš Təhillim (Midraš to Psalms; 9th to 11th century CE), 19. 13, on Psalm 19. 7, tr. William Gordon Braude, The Midrash on Psalms (Midrash Tehillim), vol. 1 ('Yale Judaica Series', 13; New Haven, Connecticut: Yale University Press, 1959), p. 282, cf. 19. 11, on Psalm 19. 5. And is 'Imprison' accurately translated?

${ }^{84}$ Isaiah, 38. 4-5, 8; 2 Kings, 20. 9-11; 2 Chronicles, 32. 24-26, 31.

${ }^{85}$ Herodotus, Histories, 2. 142; Pomponius Mela, De Chorographia (On the Description of Lands) = De Situ Orbis (On the Situation of the World), 1. 59; Solinus, Collectanea Rerum Memorabilium (Collection of Curiosities) $=$ De Mirabilibus Mundi (On the Wonders of the World), 32. 39.

${ }^{86}$ e.g., Oenopides of Chios, in Achilles Tatius, Isagoge ad Arati Phaenomena (Introduction to Aratus' Phaenomena), 24; Euripides, Orestes, 999-1005; Electra, 727-730; Plato, Politicus (Statesman), 12 (268E, 269A); pseudoApollodorus, Bibliotheca (Library): Epitome, 2. 12; Seneca, Thyestes, 776-878; Lucan, Pharsalia $=$ De Bello Civico (On the Civil War), 1. 543-544; Hyginus, Fables, 88, 258. Reminiscent of the Egyptian and Mesopotamian cases examined above, Seneca's Thyestes makes much of a sudden absolute darkness accompanying the sun's turning in its course, but this is quite clearly the result of the sun's early arrival back at the eastern horizon.

${ }^{87}$ Wilhelm Hofmayr, Die Schilluk. Geschichte, Religion und Leben eines Niloten-Stammes; Nach P. Banholzers F. S. C und eigenen Aufzeichnungen dargestellt ('Anthropos; Ethnologische Bibliothek', 2. 5; Mödling bei Wien: Verlag der Administration des Anthropos, 1925), p. 44. Godfrey Lienhardt ('The Shilluk of the Upper Nile', in Daryll Forde [ed.], African Worlds; Studies in the Cosmological Ideas and Social Values of African Peoples [London: Oxford University Press, 1954], p. 148) must have had this passage in mind when writing that 'Nyikang made the Sun shine at night so that the fight might go on.'

Culture and Cosmos 
mythos also features 'the crossing of a river, said to have been the Bahrel-Ghazal, beyond which Nyikang settled his people in their present kingdom', and both the 'crossing of the river and the fight with the Sun seem to be occurrences of great imaginative importance for the Shilluk, as they are for the Western Dinka, ${ }^{88}$ a question worth investigating is whether Biblical lore surrounding Joshua's feat and the preceding miraculous crossings of the Red Sea and the Jordan may have coloured Shilluk tradition. Christian involvement recommends itself because of the relative proximity of the medieval Christian Nubian kingdom of Alodia just to the north and the discovery of two folktales among the Shilluk which were unequivocally influenced by accounts of the garden of Eden and Jesus' virgin birth. ${ }^{89}$ That said, variants of the myth of Nyikang's struggle with the sun which bear no resemblance to Biblical material are found to circulate among the Shilluk. ${ }^{90}$ This indicates that tales of

Canggaro, also spelled 'Tšangaro' and 'wang garo', was a legendary land to the east or west, where silver - then foreign to the Shilluk - was in use.

${ }^{88}$ Lienhardt, 'Shilluk', pp. 148-149.

89 Hofmayr, Schilluk, pp. 195-196, 238-240. A Christian conduit was also suspected by Kuel Maluil Jok (Animism of the Nilotics and Discourses of Islamic Fundamentalism in Sudan [Leiden: Sidestone Press, 2010], p. 106), who did not address the sun's rôle in the Shilluk stories.

${ }^{90}$ In one variant, set in the land wang garo in dem die Sonne untergeht und schläft, und wo die Sonne so nahe ist, daß man sie mit den Fingern greifen kann', 'die nahe Sonne' proved fatal to the men in the mêlée until Nyikang tempered it: 'selbst die Sonne besprengte er, damit sie nicht so heiß brenne, und sofort hörte sie auf so heiß zu brennen wie vorher.' (Wilhelm Hofmeyer, 'Zur Geschichte und sozialen und politischen Gliederung des Stammes der Schillukneger', Anthropos, 5. 2 [1910]: p. 332) A revised version by the same author (Hofmayr, Schilluk, pp. 60-61, cf. 33-34, 43, 46, 420-421, 426-427) omits the references to the sun's low position, locates Canggaro to the east, states that its people were 'von der Sonne rot gebrannt' and has the warriors sprinkled, but not the sun: 'In diesem Moment kam Garos Vater Čang (die Sonne) von der einen Seite und Nyikang mit seinen Leuten von der anderen Seite. In der folgenden Schlacht verlor Nyikang seine Leute, die von der Sonnenhitze überwältigt, zu Boden fielen. Da aber hieb Nyikang mit der Kraft letzter Verzweiflung auf die Sonne ein, daß sie taumelte und den Kampf aufgab. ... Durch Besprengen mit Wasser erweckte Nyikang seine Leute ...' The sun's dousing is related, however, in the summary given on p. 43. According to another version, Nyikang on the same occasion 'hit the sun, and it returned to the sky' - Diedrich Westermann, The Shilluk People; Their Language and Folklore (Philadelphia, Pennsylvania: The Board of Foreign Missions of the United Presbyterian Church of N. A., 1912), p. 160. Although Hofmayr (Schilluk, p. III) 
ultimately Hebrew provenance at best modified some pre-existing Shilluk traditions. With reversal of the parts of hero and foe, the conflict between Nyikang and the pair of the sun and his son resembles the strife between Set and the father-and-son pair of Osiris and Horus in Egyptian myth.

Of special interest also is the following Chinese legend of a duke by the name of Lǔyáng, a grandson of Píng, king of Chǔ, who ruled 528-516 BCE:

Duke Luyang was engaged in a difficult [battle] with Hann [sic]. As the battle grew fiercer, the sun began to set. He raised his halberd and waved it, and the sun reversed [its course] for him by three lunar lodges. ${ }^{91}$

had reservations about the quality of Westermann's data, this variant is given in the Shilluk language and points to a tradition that the sun had been low not as a characteristic of the distant land, but of an earlier time - a common motif globally (van der Sluijs, Traditional Cosmology, pp. 22-38), itself tied to the theme of the raising of the sky.

${ }^{91}$ Líu Ān (ed.), Huáinánž̌ (Master of Huainan; 139 BCE), 6. 49-50, tr. Harold D. Roth, in John S. Major, Sarah A. Queen, Andrew Seth Meyer \& Harold D. Roth, The Huainanzi; A Guide to the Theory and Practice of Government in Early Han China; Liu An, King of Huainan ('Translations from the Asian Classics'; New York: Columbia University Press, 2010), p. 215, with note 9. The correspondence with the Biblical miracles of Joshua and Hezekiah was noted by the Jesuit missionaries Joachim Bouvet (1656-1730) and François Xavier d'Entrecolles (1664-1741), followed by Antoine Gaubil (1689-1759), in his Histoire de l'astronomie Chinoise, avec des dissèrtations ('Observations mathématiques, astronomiques, géographiques, chronologiques et physiques; tirées des anciens livres Chinois, ou faites nouvellement aux Indes, à la Chine \& ailleurs, par les Pères de la Compagnie de Jesus', 2; Paris: Rollin, 1732), p. 87. In his later years, Gaubil championed the view that Jews had imported these two stories into China between 479 and 248 BCE and the Huáinánzǐ had collapsed them into one - Traité de la chronologie Chinoise, divisé en trois parties (Paris: Treuttel et Würtz Libraires, 1814 [1749]), p. 132 note 3; 'Histoire de l'astronomie Chinoise, depuis le commencement de la monarchie Chinoise; jusqu'à l'an 206 avant Jesus-Christ', Lettres édifiantes et curieuses, écrites des missions étrangeres: Mémoires des Indes et de la Chine, 26 (1783, written after 1749): pp. 243-245. Dismissing the link with Joshua, Greswell (Fasti, p. 374) insisted that the Chinese with this tale had independently preserved their own observation of the Hezekiah event. 
52 Joshua's Celestial Miracle was not an Eclipse: the Long and the Short

During the battle fought by the Duke of Lu-yang the sun went down. Swinging his spear he beckoned to the sun, when he came back. ${ }^{92}$

There is a report that, [when Duke Hsiang of $L u$ was at war with Han, and the battle was hottest, the sun went down. The duke, swinging his spear, beckoned to it, when the sun came back for him, passing through three solar mansions.] ... The allegation that the sun returned through three mansions would therefore denote 30 degrees.

While the analogy of this tradition with the stories of Joshua, Agamemnon and Nyikang is considerably fortified by the common need to complete a battle, the structural affinity becomes especially apparent in the words of a later poet, for whom the sun was 'halted' instead of turned back:

And Lu Yang, by what power

halted evening's setting sun?

It defies Tao, offends heaven - all fake and never-ending sham. ${ }^{94}$

Several of these cross-cultural parallels were apparently never heretofore discussed in connection with Joshua's deed: those from Egypt, the Caucasus and Sudan and most of the Sumerian ones; others - the Polynesian, African, North American and Chinese ones - were noted long ago, but ignored in modern scholarship. Certainly the material from the latter far-flung regions and probably some of the other traditions must be historically unrelated to Joshua's legend, yet all conspire to give a sense of the likely Sitz im Leben of the Biblical story by exposing a

${ }^{92}$ Wáng Chōng, Lùnhéng (Critical Essays; $80 \mathrm{CE}$ ), 29. 2, tr. Alfred Forke, LunHêng, vol. 1: Philosophical Essays of Wang Ch'ung; Translated from the Chinese and Annotated (Leipzig: Otto Harrassowitz, 1907), p. 89.

93 Wáng Chōng, Lùnhéng, 5. 2, tr. Alfred Forke, Lun-Hêng, vol. 2: Miscellaneous Essays of Wang Ch'ung; Translated from the Chinese and Annotated ('Mitteilungen des Seminars für Orientalische Sprachen an der Königlichen Friedrich-Wilhelms-Universität zu Berlin', supplement to 14; Berlin: Georg Reimer, 1911), pp. 173-174. Note the different name of the protagonist in this passage. This Xiāng, duke of Lŭ, ruled 572-542 BCE.

${ }_{94}$ Lì Bái, Rì Chüxíng (Sunflight Chant; 701-742 CE), tr. David Hinton, The Selected Poems of Li Po (New York: New Directions, 1996), p. 10, cf. 124 note 10.

Culture and Cosmos 
common practice rooted in a shared archaic mindset - conjuration of celestial entities in precarious situations, notably divinely sanctioned battle. ${ }^{95}$ Remarkably, a relatively late Jewish midraš directly compares Joshua's efforts to those of 'die Zauberer der Völker' (harțumē gōy):

Josua sah die Bedrängnis der Israeliten, den Schabbat nicht zu entweihen, und er sah weiter die Zauberer der Völker die Sternbilder zurückhalten, so dass sie gegen Israel anrückten.

Was machte Josua?

Er streckte seine Hand zum Licht der Sonne aus und zum Licht des Mondes und zum Licht der Sterne und verkündete ihnen den Namen [Gottes], und jeder einzelne stand 36 Stunden still bis zum Ausgang des Schabbat ... Und die Könige der Erde hörten [es] und wunderten sich, denn es war kein [Tag] wie dieser seit dem Tage, an dem die Welt erschaffen worden war ...

\footnotetext{
${ }^{95}$ This concurs with a scholarly consensus that the words which Joshua directed at the sun and moon were a 'poem' which 'originally functioned as some form of oracle during a battle and that Joshua is not original to the poem', Dozeman, Joshua, p. 450. Compare Boling, Joshua, p. 284; Georg Fohrer, Introduction to the Old Testament (tr. David Edward Green; Nashville, Tennessee: Abingdon Press, 1968), p. 274; Matthes, 'Solstitium': p. 265; Friedrich Schwally, Semitische Kriegsaltertümer, vol. 1: Der heilige Krieg im alten Israel (Leipzig: Dieterich'sche Verlagsbuchhandlung, 1901), pp. 24-25. Eisler ('Joshua and the Sun': p. 80) offered evidence for 'Thessalian witches who ... believed that they could bring the moon down from heaven' and 'Syrian peasants who even today charm the sun to hasten its setting in order that they may at length be able to rest from their work.' Central American, Melanesian, Australian and African examples of such solar magic are supplied in Luomala, Oceanic, American Indian, and African Myths, pp. 21, 40-41, 44-45, 52. Considering such human practitioners of 'Sonnenzauber' along with legendary humans like Agamemnon, Nyikang and duke Lǔyáng, one must reject Boling's (Joshua, pp. 283-284) identification of the speaker in Joshua 10.12 as Yahweh instead of Joshua; $c f$. Dozeman, Joshua, p. 432.

${ }^{96}$ Pirqe $\mathrm{e}$ da-Rabbi ' 'Eli ęzęr (Chapters of Rabbi Eliezer; 8th century CE), 52, tr. Dagmar Börner-Klein, Pirke de-Rabbi Elieser; Nach der Edition Venedig 1544 unter Berücksichtigung der Edition Warschau 1852 aufbereitet und übersetzt ('Studia Judaica; Forschungen zur Wissenschaft des Judentums', 26; Berlin: Walter de Gruyter, 2004), pp. $728-731$ (364-365). Gerald Friedlander (Pirkê de Rabbi Eliezer (The Chapters of Rabbi Eliezer the Great) According to the Text of the Manuscript Belonging to Abraham Epstein of Vienna; Translated and
} 
54 Joshua's Celestial Miracle was not an Eclipse: the Long and the Short

In effect, Joshua would have emulated pagan sorcery by targeting the sun and moon in addition to mere stars. ${ }^{97}$ Indeed, one does not even need to look any further than the rabbinical literature for counterparts to Joshua's conjuring, for if this be believed Joshua was just repeating a manoeuvre which his direct predecessor, Moses, had performed earlier. According to Talmūdic tradition, this again included a setting of military conflict - the battle against Sihon, king of Heshbon:

The Rabbis have taught: For the sake of three the sun broke through, Moses, Joshua and Nakdimon b. Gurion. ... When did they tremble and were in anguish before Moses? When the sun broke through for Moses.

Annotated with Introduction and Indices [London: Kegan Paul, Trench, Trubner \& Co., 1916], p. 423) translated 'the magicians of Egypt', but this is not what the Hebrew says. The text rather suggests that the Canaanite kings were applying such magic. On the calculation of the 36 hours, see the earlier note.

97 The motivation of the injunction by a desire to uphold the Šabbat links this version to the Islāmic retellings cited above. The rationale of Rabbi Eliezer's version seems to be that the stoppage of the sun and moon did not occur to allow the Israelites enough time to slay their enemies, but to so impress the local sorcerers that the battle ceased and the Saturday was consequently honoured so, bearing in mind that the Jewish day begins at sunset, Joshua's peculiar day lasted from Friday sunset to Sunday sunrise. This reveals a curious or rather modern way of thinking, for the archaic opinion would surely be that the Friday could not give way to the Šabbat if the sun did not set and rise - or how could the passage of time be measured, as noted above? Compare the commentary in Mənaššę bęn Yiśrā'ēl alias Manoel Dias Soeiro, El Conciliador (The Conciliator; 1632 CE), on Joshua 10. 12, tr. Lindo, Conciliator, p. 18: ‘... this miracle was performed on the eve of the Sabbath, and inasmuch as the five kings relied on their enchantments and oracles, Joshua gave them to understand, by commanding the sun to stand still in the Divine name, that the powers on which they depended were kept in subjection to his empire; and in order that the day of rest might not be profaned, the sun was staid during the period of Sabbath, and the moon during the night of Sabbath, and of its termination, together making thirty-six hours.' In this latter interpretation, the sun and moon take turns lasting 24 and 12 hours respectively instead of conjointly resting for 36 hours along with the stars.

98 Babylonian Talmūd: Ta'anīt (Fasting Day), 3 (20a), tr. Joseph Rabbinowitz, Ta'anith; Translated into English with Notes, Glossary and Indices ('The Babylonian Talmud'; 'Seder Mo'ed'; London: The Soncino Press, 1938), p. 98. The legend of Naqdimon alias Nicodemus ben Gurion (19b-20a), who reputedly

Culture and Cosmos 
A Tanna taught: Just as the sun stood still for Joshua, so did the sun stand still for Moses and for Nakdimon b. Gorion. ... When did they tremble and were in anguish because of Moses? When the sun stood still for him.

Moses made the orb of the sun stand still ... ${ }^{100}$

A Midraš probably of a later date postulates an even earlier instance of solar pausing, on the occasion of the Israelites' battle with Amalek:

What were these two unusual days? The day of Moses which uttered speech to the day of Joshua. ... Perhaps you will say: Since the Holy One, blessed be He, had wiped out Sihon and $\mathrm{Og}$, who was left to speak of Moses to the peoples of the earth? The sun which twice stood still for Moses! The first time when he made war against Amalek ... This was the day of Moses which uttered speech to the day of Joshua ...; that is, 'Say to Joshua: "May it be the will of God that as the sun stood still for Moses, so may it stand still for thee in the war with the thirty-one kings." At the war with Sihon and with Og the sun stood still for Moses a second time. ${ }^{101}$

lived in the 1st century CE, does not involve the sun's arrest, but its breaking through clouds in response to prayer just when Nicodemus' antagonist is convinced the sun has set. It is hard to see in what way the rabbis read Joshua to the effect that the sun 'broke through'.

${ }^{99}$ Babylonian Talmūd: ' $\breve{b}$ bodā Zārāa, 2 (25a), tr. Mishcon, in Mishcon \& Cohen, 'Abodah Zarah, pp. 125-126. Anticipating the objection that Moses could not have effected the same solar anomaly as Joshua did because of the assurance in Joshua 10. 14 that no such day ever occurred before or since, the rabbis submitted the sophistic ad hoc solution that 'there was none that lasted as long as that one; or, if you wish, you may say it means that there were no hailstones [as in the case of Joshua] ...'

${ }^{100}$ Pasīqtā Rabbātì (Big Pericopes; $c 845$ CE), 4. 2, tr. William Gordon Braude, Pesikta Rabbati; Discourses for Feasts, Fasts, and Special Sabbaths; Translated from the Hebrew, vol. 1 (New Haven, Connecticut: Yale University Press, 1968), p. 87, where Moses' feat is in turn compared to a similar one attributed to Elijah, supported by 1 Kings 18.36 .

${ }^{101}$ Midraš Təhillìm, 19. 2, on Psalm 19. 3, tr. Braude, Midrash on Psalms, p. 278. Dozeman (Joshua, p. 451) linked Joshua's miracle to the battle against Amalek on the internal Biblical ground that both lasted until sunset, but showed no awareness of the rabbinical debate. 
56 Joshua's Celestial Miracle was not an Eclipse: the Long and the Short

Other sources apparently testify to yet more exhibitions during Moses' lifetime:

The day on which God revealed Himself on Mount Sinai was twice as long as ordinary days. For on that day the sun did not set, a miracle that was four times more repeated for Moses' sake. ... The sun stood still for Moses ... at the time when Moses commanded heaven and earth to stand still and listen to him, saying: 'Give ear, ye heavens, and I will speak and let the earth hear the words of my mouth.' ...

A Midrash ... reads: Moses refused to submit to the Angel of Death, saying unto him: 'I shall not die, but live, and declare the works of God.' The angel of Death replied: 'God has the sun and the moon to praise Him and to declare His glory.' Whereupon Moses bade the sun and the moon stand still and he began to praise God. ... it is said that Moses, the best of the Hebrews ... made the sun and the moon stand still. ${ }^{102}$

As is de rigueur in rabbinical discourse, the textual proofs adduced by the authorities ${ }^{103}$ are divorced from literary or historical context and do not meet scientific criteria for logical argumentation, but this does not mean that the derived 'tradition' at hand was not genuine; in contradistinction to the principles of philosophical deduction, the rabbis' modus operandi typically appears to have been to try and justify a pre-existing oral tradition on scriptural grounds - an exercise of 'isegesis' more than 'exegesis'. ${ }^{104}$ Whether the rabbis had simply extrapolated from Joshua's

${ }^{102}$ Louis Ginzberg (ed.), The Legends of the Jews, vol. 3: Bible Times and Characters from the Exodus to the Death of Moses (tr. Paul Radin; Philadelphia, Pennsylvania: The Jewish Publication Society of America, 1911), p. 109; vol. 6: Notes to Volumes III and IV; From Moses in the Wilderness to Esther (tr.; idem, 1928), pp. 45-46 note 245.

${ }^{103}$ Deuteronomy, 2. 25; Joshua, 3. 7; and in the Midraš Tahillìm also Exodus, 17. 11-12, 14; Psalms, 19. 2; Habakkuk, 3. 11.

104 Islāmic raconteurs in the genre of qișaș al-anbiyā' ('tales of the prophets') associated a prolonged night with the Israelites' exodus from Egypt, preceding their isodus into Canaan. Thus 'Urwah ibn al-Zubayr (d. $713 \mathrm{CE}$ ), in al-Ta'labī, 'Arā'is al-Majālis fi Qiṣaṣ al-Anbiyā', tr. Brinner, 'Arā'is al-Majālis', p. 327: 'God had commanded Moses to set out with the Children of Israel at the rise of dawn; so he prayed to his Lord to delay its rising until he completed the matter of Joseph, and he did so.' The 'matter of Joseph' was the retrieval of the 
to Moses' legendary biography or were drawing on an authentic aspect of tōrā šę-bə 'al $p \bar{e}$ ('oral Torah'), it seems safe to conclude that human manipulation of the course of the celestial bodies at critical moments in history was a common trope in the archaic worldview of diverse societies.

\section{Striking a Balance}

Where does the marshalled comparative evidence from the folklore of other cultures leave the possible historicity of Joshua's long day? Does the existence of parallels, both in the Eastern Mediterranean and much further afield, preclude the occurrence of some extraordinary natural event during Joshua's ruthless pursuit of the Amorites? All answers to these questions can be positioned on a spectrum between extreme literalism and extreme scepticism.

Radical literalists take the text as it stands as an accurate historical description. Typifying this position, the devoutly Christian English astronomer Edward Walter Maunder (1851-1928) - in a lengthy discussion of the subject published more than a century ago - sternly cautioned against rewriting the source to one's own liking:

But there is another thing that has also to be remembered. The narrative which we have before us, being the only one that we have, must be accepted exactly as it stands. That is the foundation of our inquiry; we have no right to first cut it about at our will, to omit this, to alter that ... A moment's reflection will show that a man who would permit himself to tamper with the sole evidence upon which he purports to work, no matter how profoundly convinced he may be that his proposed corrections are sound, is one who does not understand the spirit of science, and is not going the way to arrive at scientific truth.

Some religious minds, maintaining that no part of the text can be factually incorrect, subscribe to the traditional interpretation of a genuine

patriarch's bones (compare Exodus, 13. 19; Judges, 1. 32). Perhaps this tale was invented as an antithesis to Joshua's performance, consistent with the plague of darkness; the parallelism between the Egyptian plagues of hail and darkness and Joshua's special day was also observed by Smythe Palmer (Misunderstood Miracle, p. 40). Al-Aḥbār (in al-Kisā'̄i, Qișaș al-Anbiyā', 65, tr. Thackston, Tales of the Prophets, p. 233) passed directly from the plague of darkness, lasting three days, to the Exodus.

${ }^{105}$ Maunder, Astronomy of the Bible, pp. 352-353. 
lunisolar miracle and are happy to leave it unexplained. ${ }^{106}$ Other writers produce creative tortuous interpretations of the text - without challenging its literal veridicality - in order to render it scientifically palatable. These are reductionist in their tendency to deny that any truly fantastic natural event happened. Thus, in his cramp to uphold the literal truth of Scripture Maunder took the Hebrew words used for 'stand still' in the sense of 'be silent' or 'cease' and argued that Joshua with his utterance petitioned no more than that his men would be shielded from the scorching Palestinian summer noon sun lest fatigue would prevent them from continuing their chase - a prayer promptly answered by the thunderstorm. ${ }^{107}$ Spurred on, the soldiers marched for a distance much longer than could normally be accomplished in the same time, leading them to conclude that the motion of the sun and moon must have stagnated: 'The Israelites had no timemeasurers, could have had no time-measurers. ... the length of the march made between noon and sunset was equal to an ordinary march taking the whole of a day. ${ }^{, 108}$ Eisler was confident that the miraculous halting of the sun and moon was an illusion due to a slowed perception of time brought on by the distress of the battle. ${ }^{109}$ With their endeavour to explain away the retardation of sun and moon but still cling to the exact wording of the text Humphreys \& Waddington may be placed in the same literalist camp.

The literalist stance is often insensitive to literary genre and typically makes light of comparative-mythological evidence; if it does countenance parallels, they are dismissed as coincidental or due to the repeated historical occurrence of very similar events. Neither Maunder nor Humphreys \& Waddington cited the Homeric or any other non-Hebrew mythological match to Joshua's checking of the sun and moon. Even if adherents of a literalist persuasion would go as far as to adjust the earth's rotation to accommodate the story of Joshua, they could hardly postulate

${ }^{106}$ e.g., Soggin, Joshua, p. 123.

${ }^{107}$ Maunder, Astronomy of the Bible, pp. 374-375; 'Misinterpreted Miracle': pp. 364-367, 371-372.

${ }^{108}$ Maunder, Astronomy of the Bible, pp. 381-382, cf. 380; 'Misinterpreted Miracle': pp. 367-370. As if not quite convinced by his solution, Maunder (Astronomy of the Bible, p. 383) also left the door open to the possibility of a 'temporary arrest of the earth's rotation'. On the inability to measure the passage of time with a still sun, compare the notes above and William Brain Galloway, The Chain of Ages (1881), p. 169 (non vidi), in Smythe Palmer, Misunderstood Miracle, p. 93 note V.

${ }^{109}$ Eisler, 'Joshua and the Sun': p. 83. 
such an extraordinary mechanism for each similar instance reported in legend or myth, like the Chinese or Greek cases. For non-religious investigators it would also be too much of a stretch if the solar phenomenon - whatever it was - happened just when a man prayed for it.

At the other end of the scale, sceptics could also rest content with the conviction that there is no mystery to explain, albeit not because of a strained reading of the text but by classifying Joshua's long day as a scribe's misunderstanding, a common stylistic device of hyperbole ${ }^{110}$ or sheer mythical fancy, on a par with Egyptian and other African, Greek, Chinese, Polynesian and North American fables about a momentary arrest or a reversal of the sun. Again, nothing really unusual would have happened in nature on that day if there even was such a day; the Hebrews simply won a battle, perhaps following a ritual divination, incantation or prayer for divine support, and a memorable hailstorm may have occurred. If the figure of Joshua had not itself originated as a mythical sunconfronting hero of the type of the Polynesian Maui or the Greek Atreus or Herakles, the myth may have been the accidental result of the author of Joshua 10 gullibly interpreting the quotation from the Book of the Justperhaps an omen - as a prosaic literal description of a stupendous solar event. ${ }^{111}$ Walton, as seen, envisaged a scene in which Joshua pronounced an omen related to an opposition of the sun and moon but a severe hailstorm was the only thing of note to befall the natural environment. Smythe Palmer, who railed against 'men so enslaved to the letter', reduced the sign to a violent hailstorm poetically expressed as a 'silencing' or darkening of sun and moon. ${ }^{112}$ Even the hailstorm, part of the gods' standard repertoire of intercessional instruments, could have been fictional. The Jewish Anglo-American mythologist Theodor Herzl Gaster (1906-1992) was one who was satisfied that Joshua's miracle could be mythology pure and simple, devoid of a factual basis:

Some scholars, to be sure, have attempted to dilute the miraculous element in our Biblical story. ... Standard Bible commentaries are full of tiresome homiletical nonsense about this incident. ${ }^{113}$

\footnotetext{
${ }^{110}$ van Bekkum, From Conquest to Coexistence, pp. 294-295.

111 Younger, Ancient Conquest Accounts, pp. 213-214, citing Halpern and Bewer.

${ }^{112}$ Smythe Palmer, Misunderstood Miracle, pp. 34, 39, 115-116 note GG.

${ }^{113}$ Gaster, Myth, pp. 415, 528 note 10. So also Holzinger, Das Buch Josua, p. 40.
}

Culture and Cosmos 
60 Joshua's Celestial Miracle was not an Eclipse: the Long and the Short

The trouble with this approach is that even myths, especially nature myths, are unlikely to have been fabricated out of whole cloth; they, too, must have some sort of explanation or origin. Moreover, the book of Joshua is obviously not in the genre of myth, but rather more of legend verging on historiography. The account of the battle in which the solar episode is embedded reads as plausible and historical, with some allowance for poetic confabulation. A similar assessment could be made for the cited passages from the Iliad and Chinese literature.

Taking all this into account, an intermediate option would appear to be most warranted: some truly striking natural event happened, but the memory of it was garbled. ${ }^{114}$ On such a compromise, the comparative evidence can serve as a guide to the various ways in which certain natural events can be expressed in folklore, without any implication of an actual historical connection with the tale of Joshua. The embellishment could be blamed either on subsequent oral folk tradition, according to processes operative in myths elsewhere, or again on the author of Joshua 10 misconstruing his source. The most ancient identified parallels - those from Egypt and Mesopotamia - along with Seneca's tragedy give reason to consider that the 'standing' of sun and moon involved their sudden midday disappearance from view by some other agency than an eclipse or ordinary cloud cover; this meaning of the 'standing' was then no longer understood in Hellenistic times or perhaps as early as the time of Habakkuk or the writing of Joshua, forcing the versiones antiquae, Rabbinical exposition and derivative traditions such as perhaps Shilluk lore to envision an extended period of daylight. Alternatively, it may be that Joshua in accordance with custom requested a favourable omen or addressed the deity prior to the massacre, perhaps specifically asking for the sun and moon to be restrained in some way, but the actual event existed in a prolongation of daylight by other means than an alteration of the sun's patterns.

It is found that eclipses are never commemorated in terms of solar or lunar immobility or, obviously, prolonged daylight. However, accounts in which the daytime is extended by a few hours at most, such as the Arabic and possibly the Chinese reports, or without any mention of the sun, like Josephus' version, are quite suggestive of the evening manifestation of the zodiacal light - sunlight reflected off interplanetary dust particles

114 Compare: 'Between the uncritical literalism of the ancients ... and the sceptical naturalism of the moderns ..., the view here advanced, I am willing to think, occupies a happy mean.' Smythe Palmer, Misunderstood Miracle, p. 62.

Culture and Cosmos 
along the ecliptic plane - which at mid-latitudes is common in spring. After all, the zodiacal light's morning apparition, more typical of autumn, was frequently described as a 'false dawn', suggestive of the sun's unexpectedly early rising. This phenomenon ought to have been familiar to the Hebrews, just as it was in Arabic culture, but would have been far more conspicuous than it has been in recent centuries at times of replenishment of the cosmic dust cloud by cometary disintegration. Furthermore, in popular parlance bolides and great comets were often portrayed as sun- or moon-like or confused with these bodies. ${ }^{115}$

A vital clue might be contained in the shower of 'big stones' ('ábānìm gadolōt) or hailstones ('abnē habbārād) which struck the Amorites on the same fateful day (verse 11). The cited passages from Habakkuk and Josephus, too, are evocative of a tempestuous accompaniment, including lightning, to the alteration of the day. ${ }^{116}$ The English archaeologist and Anglican cleric William John Telia Phythian-Adams (1888-1967) unknowingly revived an old idea in his identification of the stones as meteorites, ${ }^{117}$ but was original in his adventurous - though largely forgotten - proposition that the 'long day' was an atmospheric light effect resulting from a distant meteorite impact. This would have been similar to the strange illumination of the night noticed as far away as England -

\footnotetext{
115 e.g., Seneca the Younger, Natural Questions, 7. 15. 1; Pliny, Natural History, 2. 35 (100); Michael the Syrian, Chronicle, 11. 22 (465), tr. Jean-Baptiste Chabot, Chronique de Michel le Syrien; Patriarche Jacobite d'Antioche (11661199); Éditée pour la première fois et traduite en Français, vol. 2 (Paris: Ernest Leroux, 1901), p. 507; Theophanes the Confessor, Chronicle, trs. Cyril Mango \& Roger Scott, The Chronicle of Theophanes Confessor; Byzantine and Near Eastern History AD 284-813 (Oxford: Clarendon Press, 1997), p. 683; Ho Peng Yoke, 'Ancient and Mediaeval Observations of Comets and Novae in Chinese Sources', Vistas in Astronomy, 5. 1 (1962): pp. 146 \#51*, 170 \#258, 212 \#569; Edward Hetsel Schafer, Pacing the Void; T'ang Approaches to the Stars (Berkeley, California: University of California Press, 1977), pp. 94-95; Eduard Pechuël-Loesche, Volkskunde von Loango ('Die Loango Expedition ausgesandt von der Deutschen Gesellschaft zur Erforschung Aequatorial-Africas 1873-1876. Ein Reisewerk in drei Abtheilungen', 3. 2; Stuttgart: Strecker \& Schröder, 1907), p. 135; Esteban Lucas Bridges, Uttermost Part of the Earth (New York: E. P. Dutton \& Co., 1948), p. 480.

${ }^{116}$ Compare also Job, 38. 22-23.

${ }^{117}$ Smythe Palmer (Misunderstood Miracle, pp. 33, 92 note U) enumerated sources as early as Hugo Grotius (1583-1645), but rejected the suggestion; Abel ('Stratagèmes': pp. 333-334) cited some Roman parallels but could think of no physical connection between meteorites or hailstones and the solar arrest.
}

Culture and Cosmos 
62 Joshua's Celestial Miracle was not an Eclipse: the Long and the Short

including by himself - in the summer of 1908 , following the impact over Tunguska (Siberia):

... the most remarkable of its effects was the production of an 'extraordinarily strong light' which appeared in Sweden about an hour after sunset and lasted till after two in the morning ... For two successive nights 'it failed to get dark at all in the south of England' ... This 'lengthening of the hours of daylight' was caused ... by the vast cloud of meteoric dust and smoke which was flung miles high into the air ... This cloud, it is thought, caught the sun's rays and deflected them downwards, the effect continuing even after sunset on account of its great height above the earth ...

Our suggestion then is that (as in 1908) a meteorite fell to earth in the early hours of the morning in which Israel engaged the Amorite confederacy around Gibeon. Fragments torn from it as it sped through the air showered down upon the enemy and drove them in headlong flight. The pursuit lasted all day, but when the hour came in which they might have hoped for darkness to cover their escape, the heavens remained lighted by the after-effects of the meteorite's explosion. ${ }^{118}$

A connection which Phythian-Adams did not make is that the brightening of the night as a result of meteoric dusting at altitudes well above the stratosphere, as he claimed, technically qualifies as a kindred phenomenon to the zodiacal light, with the dust in the upper atmosphere rather than interplanetary space. The apparent movement of the sun and moon would have remained unaffected or experienced some slight optical distortion due to a sudden increase in reflective particles in the upper atmosphere, but it is easy to see how the idea of their deceleration or return could have arisen as an accretion to the original eye-witness accounts. After sunset, the flyby of a bolide could have spawned a popular impression that the sun had returned or had somehow not yet set. Whereas a bolide would last minutes at most, a great comet could have been seen for hours, like a sun 'staying' in the sky; comets, however, are usually observed for multiple nights in a row - in contrast to the one-off event of Joshua's time. Alternatively, the tradition could at first have been worded along the lines of Josephus' report, omitting any reference

${ }^{118}$ William John Phythian-Adams, 'A Meteorite of the Fourteenth Century B.C.', Palestine Exploration Quarterly, 78. 2 (1946): pp. 116-117, 119. 
to the sun or moon. As suggested above, a subsequent storyteller could have mistakenly inferred from the extension of daylight hours that the sun - perchance along with the moon - had remained in the sky for much longer than it is wont to do. Words to that effect could have been written into Joshua's incantation, or perhaps a war oracle or a divination of the nature examined above already mentioned these celestial bodies, thereby reinforcing the notion that they were actively involved in the portent.

It might seem too much of a coincidence that meteorite falls should attend a military campaign, but incontestible examples are on record. On 7 November 1492, king Maximilian I of Habsburg (1459-1519), heir to the Holy Roman Empire, was preparing for an offensive against the French when pieces of a large disintegrating stony meteorite landed in the surroundings of nearby Ensisheim (northeastern France), accompanied by a loud boom and lightning - 'the oldest preserved fall of which appreciable remains are extant and available for research'; ${ }^{119}$ availing himself of the opportunity to inspect the donnerstein ('thunderstone') for himself on the 26th of the same month, the king assembled a council which decided that the fall was a favourable omen for success in the wars with France and Turkey. ${ }^{120}$

In 74 BCE, at the onset of the Third Mithridatic War, a large meteorite fell amidst the facing armies of Roman consul Lucius Licinius Lucullus (118-c57 BCE) and king Mithridates VI of Pontus (d. 63 BCE) on the shores of Lake Ascania (now Lake İznik, northwest Turkey):

... as they were on the point of joining battle, with no apparent change of weather, but all on a sudden, the sky burst asunder, and a huge, flame-like body was seen to fall between the two armies. In shape, it was most like a winejar, and in colour, like molten silver. Both sides were

119 Ingrid Drake Rowland, 'A Contemporary Account of the Ensisheim Meteorite, 1492', Meteoritics, 25. 1 (1990): p. 19.

${ }^{120}$ Sebastian Brant, Von dem Donnerstein gefallẽ im xcij. Iar: Vor Ensishein (Basel: Michael Furter, 1492); Erik Gregersen (ed.), The Outer Solar System; Jupiter, Saturn, Uranus, Neptune, and the Dwarf Planets ('An Explorer's Guide to the Universe'; New York: Britannica Education Publishing, 2010), p. 87; Michael D. Reynolds, Falling Stars; A Guide to Meteors \& Meteorites (Mechanicsburg, Pennsylvania: Stackpole Books, 2010²), p. 55; Darin Hayton, The Crown and the Cosmos; Astrology and the Politics of Maximilian I (Pittsburgh, Pennsylvania: University of Pittsburgh Press, 2015). In the opinion of the Italian chronicler Sigismondo Tizio, however, the meteorite presaged disaster - Rowland, 'Contemporary Account': p. 19. 
64 Joshua's Celestial Miracle was not an Eclipse: the Long and the Short

astonished at the sight, and separated. This marvel, as they say, occurred in Phrygia, at a place called Otryae. ${ }^{121}$

Closer in time still to Joshua's legendary life, at c1446-1444 BCE, is a 'miracle' (bj3yt) reported by king Thutmose III of Egypt which involved the unexpected nocturnal appearance of a flaming 'star' ( $\left.s b_{3}\right)$ during a confrontation between his army and that of Mitanni:

... then you will know the miracle of [Amun-Re] in the presence of the Two Lands. [...] not [... sentr]ies were in the very act of being posted at night in order to do their regular watch. There were two astronomers (present). A star approached, coming to the south of them. The like had not happened before. It shot straight toward them (the enemy), not one of them could stand [...] falling headlong. Now then [...] was behind them with fire in their faces. Not one of them retaliated; no one looked back. Their chariotry is gone, they (the horses?) having bolted in [...] in order that all foreigners might see the awe of my majesty. ${ }^{122}$

In the prologue to this text, the triumphant king is himself eulogised as the embodiment of the star coursing between the two wings of his army as if between the 'bows' or 'arcs' of the sky and exercising his might through the serpent worn on his diadem:

He is one who immediately overwhelms all foreign lands while at the head of his army, as he shoots between the two

121 Plutarch, Life of Lucullus (Vita Luculli), 8. 6-7, tr. Bernadotte Perrin, Plutarch's Lives, vol. 2: Themistocles and Camillus; Aristides and Cato Major; Cimon and Lucullus ('Loeb Classical Library', 47; London: William Heinemann, 1914), pp. 494-497; cf. Massimo d'Orazio, 'Meteorite Records in the Ancient Greek and Latin Literature: Between History and Myth', in Luigi Piccardi \& William Bruce Masse (eds.), Myth and Geology ('Geological Society Special Publication', 273; London: The Geological Society, 2007), p. 218, who mistakenly gave Lucullus' first name as 'Caius'.

122 Jebel Barkal Stela, 33-37, ed. Adriaan de Buck, Egyptian Readingbook, vol. 1: Exercises and Middle Egyptian Texts Selected and Edited (Leiden: Nederlandsch Archaeologisch-Philologisch Instituut voor het Nabije Oosten, 1948), pp. 56-63, tr. James K. Hoffmeier, 'The Gebel Barkal Stela of Thutmose III (2. 2B)', in William Wolfgang Hallo \& Kenneth Lawson Younger (eds.), The Context of Scripture; Canonical Compositions, Monumental Inscriptions, and Archival Documents from the Biblical World, vol. 2: Monumental Inscriptions from the Biblical World (Leiden: Brill, 2003), p. 17.

Culture and Cosmos 
divisions of troops, like a star he crosses the sky, entering into the throng, [while a bl] ast of his flame is against them with fire, turning into nothing those who lie prostrate in their blood. It is his uraeus that overthrows them for him, his flaming serpent that subdues his enemies, with the result that numerous armies of Mitanni were overthrown in the space of an hour, annihilated completely like those who had not existed, in the manner of those who are burned ... ${ }^{123}$

Despite this stylistic method, the assurance that 'The like had not

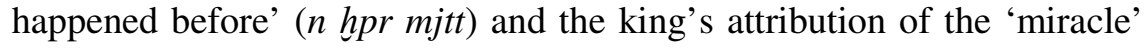
to his god Amun-Re can only mean that the celestial apparition actually eventuated. ${ }^{124}$ The 'astronomers' (wnwtj) were probably 'experts in reading signs in the heavens to predict the outcome of his ventures. ${ }^{125}$ The star's devastating effects upon the pharaoh's enemies under the guise of a fiery uraeus and the proclaimed uniqueness of the event indicate something truly alarming like an impacting bolide. ${ }^{126}$ Hoffmeier argued that an Egyptian scribal tradition like that epitomised in Thutmose III's annals influenced the literary composition of Joshua 1-11, but

${ }^{123}$ Jebel Barkal Stela, 5-7, tr. Hoffmeier, 'Gebel Barkal Stela', pp. 14-15. See Barbara Cumming (tr.), Egyptian Historical Records of the Later Eighteenth Dynasty, vol. 1 (Warminster: Aris \& Phillips, 1982), p. 6 on the word here translated as 'blast' $(s \check{s} d)$.

${ }^{124}$ So also Friedrich, 'Himmelszeichen': p. 139.

${ }^{125}$ Cumming, Egyptian Historical Records, p. 7.

${ }^{126}$ Younger (Ancient Conquest Accounts, p. 217) guessed that the phenomenon could have been 'a comet or supernova'. Weinfeld inferred that 'a comet fell out of its fixed place' ('Divine Intervention', p. 127) or that the object was a 'meteorite' (p. 139). Cumming (Egyptian Historical Records, p. 7) preferred 'a meteorite or possibly the phenomenon called ball lightning'. Wolfgang Helck (Urkunden der 18. Dynastie; Übersetzung zu den Heften 17-22 ['Urkunden des ägyptischen Altertums'; Berlin: Akademie-Verlag, 1961], p. 6) suggested 'Meteor', but also remarked (p. 10 note 5): 'Welche Art von "Stern" da jedoch gerade "von Süden her" gegen sie aufgeht, bleibt undeutbar.' For some Assyrian parallels, see Weinfeld, 'Divine Intervention', pp. 139-140; Gerd Steiner, 'Ein Bolid in Anatolien als Manifestation einer Gottheit', in Hannes D. Galter (ed.), Die Rolle der Astronomie in den Kulturen Mesopotamiens; Beiträge zum 3. Grazer Morgenländischen Symposion (23.-27. September 1991) ('Grazer Morgenländische Studien', 3; Graz: GrazKult, 1993), pp. 223-224 and, without a military context, 228-229. 
66 Joshua's Celestial Miracle was not an Eclipse: the Long and the Short

surprisingly did not list the decisive celestial marvels as a point of agreement between the two works. ${ }^{127}$ Younger did. ${ }^{128}$

A final example concerns the entry for the third year of rule in the Ten Year Annals of the Hittite king Muršili II (c1318 BCE). In this, the king in his own voice recounts the catastrophic daytime descent of a 'thunderbolt' onto the inimical land of Arzawa (southwest Anatolia) and its city Apāša, to which he happened to be marching at that very moment:

I marched to Arzawa. I sent a messenger to Uhha-ziti, writing to him: '.. let us do battle, and the Storm-God, My Lord, shall judge our case!' When I had set out and arrived at Mt. Lawasa, the Storm-God, My Lord, made manifest his providence. He launched a lightning bolt, and my army saw the lightning bolt, as did the land of Arzawa. The lightning bolt traveled and struck the land of Arzawa, (in particular) Apasa, the city of Uhha-ziti. Uhha-ziti fell on his knees and became ill, and being ill, he did not come against me in battle again. ... I ... crossed the territory of Arzawa and entered Apasa, city of Uhha-ziti. Uhha-ziti did not offer me resistance but ran away from me. ${ }^{129}$

In the corresponding section of the Extensive Annals, it is the land of 'Hatti' instead of 'my army' which watched the spectacle and it is added that Muršili was then at 'the Sehiriya River', ${ }^{130}$ which must be today's Sakarya, the Sangarius of the Greeks. The exact meaning of the Hittite word here translated as 'lightning bolt' ( ${ }^{\mathrm{GIS}}$ kalmišana) is a bone of contention. Etymologically, the sense 'piece of firewood, firebolt' seems inarguable, ${ }^{131}$ but even if the Hittites restricted this to what they called

127 James Karl Hoffmeier, 'The Structure of Joshua 1-11 and the Annals of Thutmose III', in Alan Ralph Millard, James Karl Hoffmeier \& David W. Baker (eds.), Faith, Tradition, and History; Old Testament Historiography in its Near Eastern Context (Winona Lake, Indiana: Eisenbrauns, 1994), 165-179.

${ }^{128}$ Younger, Ancient Conquest Accounts, pp. 217-219.

${ }^{129}$ Muršili II, Ten Year Annals, 16'-17' (A ii 8-9, 13-21, 28-30), year 3, trs. Gary Michael Beckman, Trevor Robert Bryce \& Eric H. Cline, The Ahhiyawa Texts ('Writings from the Ancient World', 28; Atlanta, Georgia: Society of Biblical Literature, 2011), pp. 14-16.

${ }^{130}$ Extensive Annals, 5' (B ii 24', A ii 2'-13'), trs. Beckman et al., Ahhiyawa Texts, pp. 32-33, cf. 47.

131 Alwin Kloekhorst (ed.), Etymological Dictionary of the Hittite Inherited Lexicon ('Leiden Indo-European Etymological Dictionary Series', 5; Leiden: Brill, 2008), p. 431 s.v. 'kalmara-'.

Culture and Cosmos 
lightning ${ }^{132}$ the ancient notion of lightning differed from today's. Meteorites were often popularly perceived as 'thunderstones' in different cultures, the Ensisheim rock being just one example among many. ${ }^{133}$ Phythian-Adams made a compelling case that the object striking Arzawa was a meteorite:

That it was a meteorite of great size is shown by the fact that its arrival was witnessed by the Hittite army on the central plateau of Asia Minor (actually somewhere on the river Sangarius), while Apasas was on the seacoast about 300 miles away. ${ }^{134}$

A contemporary researcher determined: 'Die Flugbahn muß ziemlich flachwinklig gewesen sein, da Muršili bei der Beobachtung des Boliden die Grenze von Arzawa noch nicht erreicht hatte, dieser danach aber noch das ganze Land Arzawa überquerte. ${ }^{135}$ If this really was a meteorite fall, which - judging by the character BÚN in a poorly understood part of the text - may have been accompanied by a thunderous bang, it would be 'die älteste bekannte Beschreibung eines Boliden. ${ }^{136}$ It was probably this very same space rock which was famously venerated at Ephesus - the Hittite 'Apāša' - in classical times, perhaps with other portions surviving at Pessinus and Perga. ${ }^{137}$

\footnotetext{
${ }^{132}$ The translation 'thunderbolt' was given in Trevor Bryce, The Kingdom of the Hittites (Oxford: Oxford University Press, 2005), p. 194; Kang, Divine War, pp. 67-68; Weinfeld, 'Divine Intervention', p. 139; Hoffner, 'Histories': p. 328; and Friedrich, 'Himmelszeichen': p. 137 ('Donnerkeil'). Horst Klengel (Geschichte des hethitischen Reiches ['Handbuch der Orientalistik', 1: 'Der nahe und mittlere Osten', 34; Leiden: Brill, 1998], p. 189 note 225) refrained from speculation.

${ }^{133}$ Steiner ('Ein Bolid', p. 222 note 40) cited a possibly analogous case of a folkloristic designation of a falling meteorite as a 'flaming log'.

${ }^{134}$ Phythian-Adams, 'Meteorite': pp. 119-120, seconded in Steiner, 'Ein Bolid', p. 220 note 34; Mary Elizabeth Cooper, 'Uhha-Ziti, King of Arzawa: Tantalus, King of Lydia', Talanta, 44 (2012): pp. 87-89. Younger (Ancient Conquest Accounts, p. 208) also translated 'meteor'.

${ }^{135}$ Steiner, 'Ein Bolid', p. 222, cf. 219.

${ }^{136}$ Steiner, 'Ein Bolid', p. 220.

137 Cooper, 'Uhha-Ziti': pp. 99-100; Phythian-Adams, 'Meteorite': p. 120. Cooper ('Uhha-Ziti': pp. 81, 89-97, 100-101) also advanced the interesting suggestion that the Greek myth of the ominous rock suspended over Tantalus derived from the memory of the injury which this meteorite inflicted on king Uhhaziti.
} 
68 Joshua's Celestial Miracle was not an Eclipse: the Long and the Short

Friedrich discerned a similarity between the celestial events reported by Thutmose III and Muršili II and a generic kinship with Joshua's solar event, ${ }^{138}$ but it is curious that he detected more of a literary device in Muršili's treatment of the subject than in Thutmose's; he seems to have missed the references to the king as the star in the opening paragraphs of the Jebel Barkal Stela and the connection with the 'stones from heaven' in Joshua; the latter link seems to have been spotted only very rarely. ${ }^{139}$ Phythian-Adams equated the meteoric progenitor of the Arzawan meteorite with the very body he held responsible for the shower of stones and the long day of Joshua, but this required the unappealing conjecture that the battle against the Amorites took place long after Joshua. ${ }^{140}$ Regardless, Muršili's apparent confidence prior to the hostilities that the storm god would settle the disagreement is similar enough to Joshua's entreaty to Yahweh to relate both to pre-campaign oracles, just possibly inspired by detection of the visitor from space prior to impact. ${ }^{141}$ Perhaps it was because of like experiences that Babylonian astrologers formulated predictions of this sort:

If a star which is like a torch, i. e. like a reed torch, flashes from east to west and sets: the main army of the enemy will fall. ${ }^{142}$

\footnotetext{
${ }^{138}$ Friedrich, 'Himmelszeichen': pp. 136-139.

139 Younger, Ancient Conquest Accounts, pp. 208-209.

${ }^{140}$ Phythian-Adams, 'Meteorite': pp. 120-124. Soggin (Joshua, p. 123) tossed out the babe with the bathwater when he rejected Phythian-Adams' idea on grounds which only apply if the Joshua event was the same as the Muršili event, i.e., the chronological discrepancy and the long distance over which the persistent light would have to have been seen. Of course, the events could have been similar but different.

${ }^{141}$ Steiner ('Ein Bolid', pp. 225-230) offered an excellent evaluation of Muršili's account in relation to mantic literature.

${ }^{142}$ Ašarēdu the Elder (7th century BCE), 83-1-18, 174 = RMA 202, recto 5-9, tr. Hermann Hunger, Astrological Reports to Assyrian Kings ('State Archives of Assyria', 8; Helsinki University Press, 1992), p. 189 \#335. Judith Kingston Bjorkman ('Meteors and Meteorites in the Ancient Near East', Meteoritics, 8. 2 [1973]: p. 92, cf. 97-99) confidently identified this 'star' as a bolide and translated: "If a shooting star flashes (as bright) as a light or as a torch from east to west and disappears (on the horizon): the army of the enemy will be slain in its onslaught."
}

Culture and Cosmos 


\section{Conclusion}

Summing up, a solar eclipse cannot satisfactorily account for the tale of Joshua's bidding of sun and moon either on the terms of its literal wording or on the cultural-astronomical basis of the perception of eclipses in other cultures worldwide. A comparative study of myth, magical practice and historical battle accounts supports the view that at least the final editor of Joshua 10 believed the sun and moon to have literally stalled in the sky, but that he paradoxically could have related that either to a shortening or a lengthening of the period of daylight, the former more in line with the Egyptian myth of Horus, a Sumerian lamentation, Seneca's Thyestes, various African and North American tales and a stormy setting, the latter with the received Hebrew tradition and parallels in Sudanese, Caucasian, Chinese and Polynesian mythology.

As for what really transpired, the solar antics could have been merely wishful, as in Agamemnon's prayer or magicians' stock threats, or could have been the fruits of secondary imagination, be it by misinterpretation of an old war oracle, a bright meteor or comet suddenly manifesting as if the sun stayed in the sky after sunset, a strange illumination of the night following a meteorite shower as likely mentioned in the text, or a combination of these. This assessment may be disturbingly indefinite as it stands, but at the end of the day it may be better to be roughly right than precisely wrong.

\section{Acknowledgments}

I express my profound gratitude to the Mainwaring Archive Foundation for its support, an anonymous reviewer for valuable suggestions, Ev Cochrane for supplying copies of Cohen, Hall and Steiner at short notice, Dr. Hasan M. ElShamy for help with the Arabic used in al- ${ }^{-}$a'labī, Robert J. Johnson for editorial suggestions for a very early draft and Dr. Albert van der Heide for attempting to locate the Joshua passage in Abraham Šālōm. 